NBER WORKING PAPER SERIES

\title{
GLOBALISATION, PASS-THROUGH AND THE OPTIMAL POLICY RESPONSE TO EXCHANGE RATES
}

Michael B. Devereux

James Yetman

Working Paper 20252

http://www.nber.org/papers/w20252

\author{
NATIONAL BUREAU OF ECONOMIC RESEARCH \\ 1050 Massachusetts Avenue \\ Cambridge, MA 02138 \\ June 2014
}

University of British Columbia, Vancouver, BC V6T 1Z1, Canada and Bank for International Settlements, 78th Floor, Two IFC, 8 Finance Street, Central, Hong Kong. The opinions in this paper are those of the authors are not necessarily shared by the Bank for International Settlements. We thank Lillie Lam, Pablo Garcia-Luna, Giovanni Sgro and Bat-el Berger for excellent research assistance and Aaron Mehrotra, Ippei Fujiwara and participants of seminars at the Reserve Bank of Australia and University of Canterbury and conferences hosted by the People's Bank of China-BIS, Reserve Bank of New Zealand and City University of Hong Kong-JIMF for helpful comments. Any remaining errors are solely our responsibility. This research was partly supported by ESRC research grant RES-062-23-3080. The views expressed herein are those of the authors and do not necessarily reflect the views of the National Bureau of Economic Research.

NBER working papers are circulated for discussion and comment purposes. They have not been peerreviewed or been subject to the review by the NBER Board of Directors that accompanies official NBER publications.

(C) 2014 by Michael B. Devereux and James Yetman. All rights reserved. Short sections of text, not to exceed two paragraphs, may be quoted without explicit permission provided that full credit, including (C) notice, is given to the source. 
Globalisation, Pass-through and the Optimal Policy Response to Exchange Rates

Michael B. Devereux and James Yetman

NBER Working Paper No. 20252

June 2014

JEL No. F3,F41

\begin{abstract}
$\underline{\text { ABSTRACT }}$
In this paper we examine how monetary policy should respond to nominal exchange rates in a New Keynesian open economy model that allows for a non-trivial role for sterilised intervention. The paper develops the argument against the backdrop of the evolving policy-making environment of Asian economies. Sterilised intervention can be a potent tool that offers policymakers an additional degree of freedom in maximising global welfare. We show that the gains to sterilised intervention are greater when goods market integration is low and exchange rate pass-through is high. However, increased financial internationalisation reduces the effectiveness of sterilised intervention, as the international policy trilemma becomes more relevant. Unsterilised intervention may also have a role to play, although the potential welfare gains from this are generally smaller.

Most central banks in Asia have actively used sterilised foreign exchange intervention as a policy tool to smooth exchange rates. But, over time, declining exchange rate pass-through and the increasing international integration of financial and goods markets will tend to reduce the efficacy of sterilised intervention. Given the limited effectiveness of unsterilised intervention, our model implies that the role of exchange rate movements in the optimal setting of monetary policy in Asia is decreasing.
\end{abstract}

\author{
Michael B. Devereux \\ Department of Economics \\ University of British Columbia \\ 997-1873 East Mall \\ Vancouver, BC V6T 1Z1 \\ CANADA \\ and NBER \\ mbdevereux@gmail.com \\ James Yetman \\ Bank for International Settlements \\ Senior Economist \\ 8 Finance Street, Central \\ Hong Kong SAR \\ james.yetman@bis.org
}




\title{
Globalisation, pass-through and the optimal policy response to exchange rates
}

\author{
Michael B Devereux and James Yetman ${ }^{1}$
}

\begin{abstract}
In this paper we examine how monetary policy should respond to nominal exchange rates in a New Keynesian open economy model that allows for a non-trivial role for sterilised intervention. The paper develops the argument against the backdrop of the evolving policy-making environment of Asian economies. Sterilised intervention can be a potent tool that offers policymakers an additional degree of freedom in maximising global welfare. We show that the gains to sterilised intervention are greater when goods market integration is low and exchange rate pass-through is high. However, increased financial internationalisation reduces the effectiveness of sterilised intervention, as the international policy trilemma becomes more relevant. Unsterilised intervention may also have a role to play, although the potential welfare gains from this are generally smaller.
\end{abstract}

Most central banks in Asia have actively used sterilised foreign exchange intervention as a policy tool to smooth exchange rates. But, over time, declining exchange rate pass-through and the increasing international integration of financial and goods markets will tend to reduce the efficacy of sterilised intervention. Given the limited effectiveness of unsterilised intervention, our model implies that the role of exchange rate movements in the optimal setting of monetary policy in Asia is decreasing.

Keywords: globalisation; foreign exchange intervention; exchange rate pass-through

JEL classifications: E58, F62

\section{Introduction}

How should central banks respond to exchange rate changes? Historically, economies in Asia have placed a high weight on nominal exchange rate stability. Moreover, stabilising the external value of the currency appears to have served as an effective nominal anchor for the economies in the region. But, Asian economies have been changing rapidly in terms of their industrial and financial market structure, and the choice of optimal nominal anchor is likely to evolve along with these changes. In this paper, we assess the nature of structural changes in Asian economies, and discuss their implications for the role of the nominal exchange rate in monetary policy.

In the past, goods market integration was relatively low in Asia. Domestic consumption was heavily weighted towards domestically produced goods, and trade was concentrated in raw material imports and finished good exports intended for the so-called advanced economies. The degree of exchange rate pass-through to domestic prices also tended to be high. Any change in the exchange rate was likely to quickly show up as a corresponding change in domestic price levels. Under such conditions, there is a high degree of complementarity between exchange rate stability and inflation stability, and exchange rate changes can play a powerful real role by generating expenditure switching.

Another key characteristic of previous decades was relatively low levels of financial internationalisation. Domestic financial markets were relatively underdeveloped. External investors had little choice of domestic assets that they could purchase, and effective capital controls further limited the scope for international risk sharing. In such an environment, official holdings of foreign exchange reserves may be an effective substitute for private holdings in increasing international risk sharing and improving global welfare.

\footnotetext{
University of British Columbia, Vancouver, BC V6T 1Z1, Canada and Bank for International Settlements, 78th Floor, Two IFC, 8 Finance Street, Central, Hong Kong. The opinions in this paper are those of the authors are not necessarily shared by the Bank for International Settlements. We thank Lillie Lam, Pablo Garcia-Luna, Giovanni Sgro and Bat-el Berger for excellent research assistance and Aaron Mehrotra, Ippei Fujiwara and participants of seminars at the Reserve Bank of Australia and University of Canterbury and conferences hosted by the People's Bank of China-BIS, Reserve Bank of New Zealand and City University of Hong Kong-JIMF for helpful comments. Any remaining errors are solely our responsibility.
} 
But, as we document below, these three characteristics have changed. Goods markets have become more integrated in Asia as consumer preferences across different economies have moved closer together. By most metrics, the degree of exchange rate pass-through has fallen. As average inflation rates have come down, prices have tended to become stickier, slowing the rate at which exchange rate shocks are passed on to domestic price levels. Also, regional financial markets are now more integrated with global markets. Clearly there are still large deviations from complete international risk sharing but the combination of developing domestic financial markets in the region, and declining barriers to international capital flows, have seen increased financial globalisation.

We capture these characteristics in a New Keynesian model in the following ways. Increases in the degree of goods market integration are represented by a reduction in the degree of home bias in the consumer's utility function. To allow for variation in the degree of underlying exchange rate passthough, our model assumes that some portion of imports is priced in local currency, with the remainder priced in the producers' currency. In addition, we have varying degrees of financial integration, from financial autarky to full international risk-sharing.

This paper argues that these trends in exchange rate pass-through and financial market and goods market integration have important implications for the conduct of monetary policy. In particular, the effect of these developments is to reduce the gains to using sterilised intervention to influence exchange rates. In the limit, as financial internationalisation increases, sterilised intervention becomes incapable of influencing exchange rates at all. And if goods market integration were to become complete, we find that there would be no gains in welfare terms from influencing exchange rates using either sterilised or unsterilised intervention.

Although increasing financial integration reduces the usefulness of sterilised intervention, this does not leave policymakers completely without effective tools for influencing exchange rates. In response to both productivity and cost-push shocks, there generally remains a small role for unsterilised intervention to improve global welfare.

While our model is highly stylised along a number of dimensions (for example, we do not include a role for investment, or a mercantilist motive for foreign exchange intervention), we view our model as capturing some of the most salient features of some of the middle- and higher-income economies in Asia, such as Korea, Malaysia and Thailand, who follow an inflation target in addition to substantiallysterilised interventions in foreign exchange markets. The connection between these economies and the experiments undertaken with the model is developed more fully below.

Our paper adds to the existing literature on the desirability of stabilising exchange rates. ${ }^{2}$ For example, Taylor (2001) reviews the literature on including the exchange rate in monetary policy reaction functions and finds that this can result in only modest improvements (or even a deterioration) in terms of output and inflation outcomes in standard small open economy macro models. Garcia et al (2011) argue that a central bank response to exchange rates may be desirable, especially in financially vulnerable economies (defined as those where agents have limited access to saving and borrowing facilities, limiting inter-temporal optimisation). ${ }^{3}$ Sutherland (2005) shows that the optimal variance of exchange rates depends on a variety of factors, including the degree of pass-through, the size and openness of the economy, the elasticity of labour supply and the volatility of foreign producer prices.

Engel (2011) argues that monetary policy should respond to currency misalignments, which cause inefficient outcomes because home and foreign households pay different prices for the same goods. Corsetti and Pesenti (2005) demonstrate that using monetary policy to reduce exchange rate volatility may be welfare enhancing, even if it leads to increased output gap volatility, because risk-averse foreign exporters are likely to reduce average mark-ups in response to decreased exchange rate volatility. Devereux (2004) shows that, in a world with nominal rigidities and incomplete international financial markets, then, even if a flexible nominal exchange rate would serve as a perfect shock absorber, fixed exchange rates may be preferable. Effectively, flexible exchange rates can lead to inefficient output responses to demand shocks in that output may be too stable. In this paper, we obtain similar results to Devereux in the case of financial autarky. However, we find that this argument is weakened as financial markets become more internationalised.

See Mussa et al (2000) for a summary of the various factors that may influence the optimal choice of exchange rate regime.

See also Cespedes et al (2004) and Moron and Winkelried (2005). 
In the next section we discuss the recent evolution of Asian economies, focusing on changes that might warrant a reconsideration of the role of exchange rates in monetary policy. We provide empirical support for the three key elements of our model - increasing goods and financial market integration and decreasing exchange rate pass-through - based on the recent experience of nine Asian economies. Section 3 discusses the range of possible policy responses to exchange rate developments. In Section 4 we outline an open economy model that we use to analyse the effect of on-going changes in Asian economies, and their implications for the use of both sterilised and unsterilised intervention. We discuss the results from our model in Section 5. Finally, Section 6 concludes.

\section{The evolution of emerging Asian economies}

Recent decades have witnessed many changes in the structure of Asian economies. Three factors are of particular relevance to the traditional desire by central banks in the region to stabilise nominal exchange rates. First, exchange rate pass-through to inflation appears to now be low. To show this, we estimate a simple vector autoregression, economy-by-economy, on quarterly data for real GDP growth, inflation, the change in the policy rate and the change in the nominal effective change rate, in that order. ${ }^{4}$ We also include four seasonal dummies and three lags. The model is identified by orthogonalising the reduced-form errors by means of a Choleski decomposition of the variancecovariance matrix. We then compute the impulse response of inflation, in per cent, to a $10 \%$ depreciation shock to the nominal effective exchange rate. We use Monte Carlo methods and plot the median projection along with the $10^{\text {th }}$ and $90^{\text {th }}$ percentiles (as confidence bands) in Graph $1 .^{5}$

Our results suggest that exchange rate pass-through for many economies in Asia has been low for some time. The point-estimate of the peak increase in inflation following a $10 \%$ depreciation in the nominal effective exchange rate is $0.7 \%$ or lower for most economies, with the exceptions of Hong Kong $(1.1 \%)$, China (1.3\%) and Indonesia (2.6\%). However, the relatively high rate of pass-through in Indonesia is driven entirely by observations around the time of the Asian Financial Crisis: if we instead start the data sample in 2001 , for example, the peak increase in inflation drops to $1.0 \%$.

We are not the first to question the received wisdom that exchange rate pass-through remains high in emerging market economies. Brun-Aguerre et al (2012) find that short-run pass-through in emerging market economies is low and close to that for advanced economies. ${ }^{6}$

The literature offers a number of possible explanations for declining exchange rate pass-through that are likely to apply in the Asian context. For example, improved inflation control, leading to declines in both the level and volatility of inflation, is associated empirically with lower levels of exchange rate pass-through, as prices become more sticky (Devereux and Yetman, 2010; Choudry and Hakura, 2006; Gagnon and Ihrig, 2004). ${ }^{7}$ For Asian economies with a history of high inflation, the improvement in inflation outturns has been substantial. Average inflation in China and Indonesia declined by almost one half from 1993-2002 to 2003-2012. Most other regional economies have seen substantial, although smaller, declines in inflation between these same two periods. Other explanations include changes in the composition of import bundles, from high pass-through commodities to lower passthrough manufactured goods and food products (Campa and Goldberg, 2005) and increased trade in final goods (Choi and Cook, 2013).

4 Our variables are defined as the quarter-on-quarter change in the log of the level for real GDP, the CPI and the nominal effective exchange rate, and the change in the level for the policy rate.

5 Sample periods depend on data availability and vary between 1994Q1-2012Q4 (China, Hong Kong, Korea, Malaysia, Philippines, Thailand), 1994Q1-2012Q3 (Singapore), 1996Q1-2012Q4 (Indonesia) and 1996Q2-2012Q3 (India).

6 See, also, Ca'Zorzi et al (2007) and Mihaljek and Klau (2008).

7 Care should be taken in giving a decline in pass-through a structural interpretation, however. Improved inflation outcomes are likely to present as evidence of declining pass-through regardless of any underlying structural changes. This is because, the more stable inflation is, the less correlated inflation will tend to be with any potential explanatory variables, including exchange rates, as Parsley and Popper (1998) argue. Similarly, Reyes (2007) argues that successful currency intervention to smooth exchange rate changes may result in the appearance of reduced pass-through, even if pricing behaviour is unchanged. 

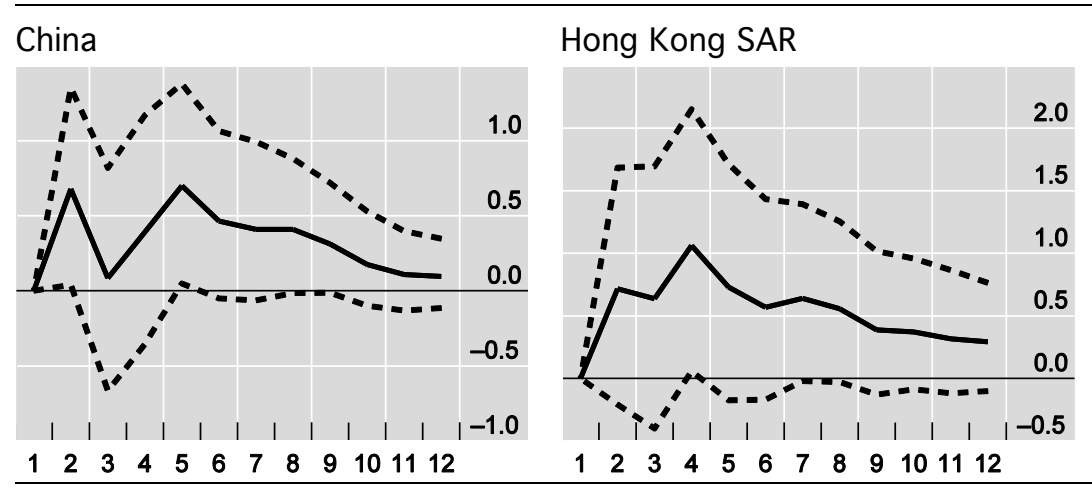

\section{Indonesia}

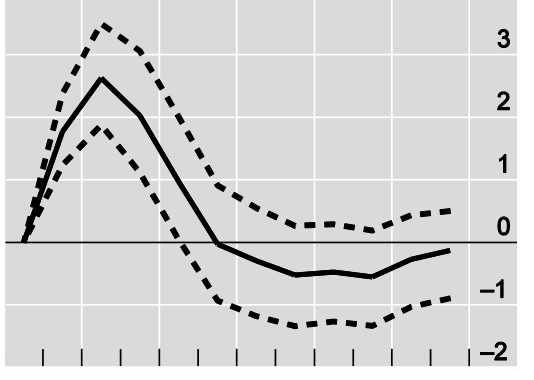

$\begin{array}{lllllllllllll}1 & 2 & 3 & 4 & 5 & 6 & 7 & 8 & 9 & 10 & 11 & 12\end{array}$

Philippines

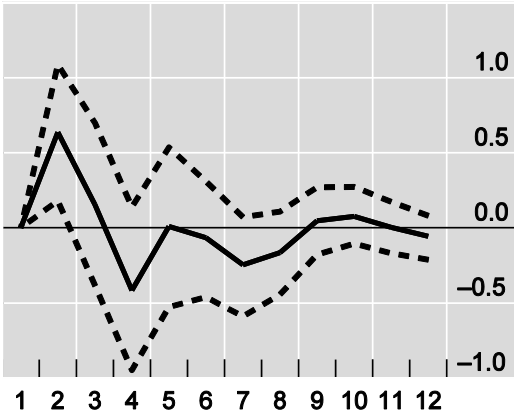

\section{Korea}

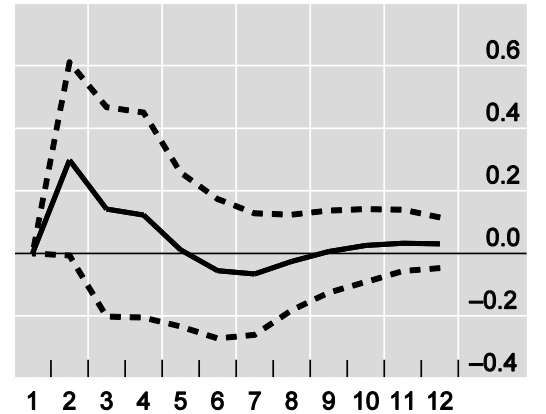

$\begin{array}{lllllllllllll}1 & 2 & 3 & 4 & 5 & 6 & 7 & 8 & 9 & 10 & 11 & 12\end{array}$

Singapore

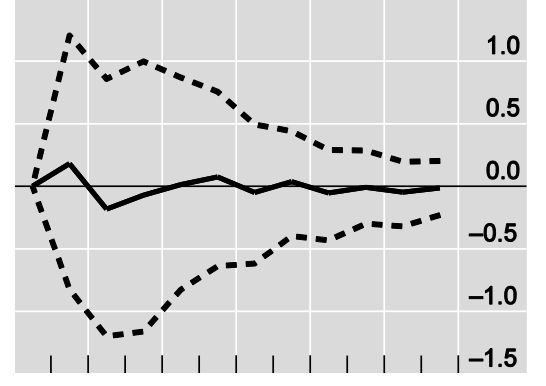

$\begin{array}{lllllllllllll}1 & 2 & 3 & 4 & 5 & 6 & 7 & 8 & 9 & 10 & 11 & 12\end{array}$
India

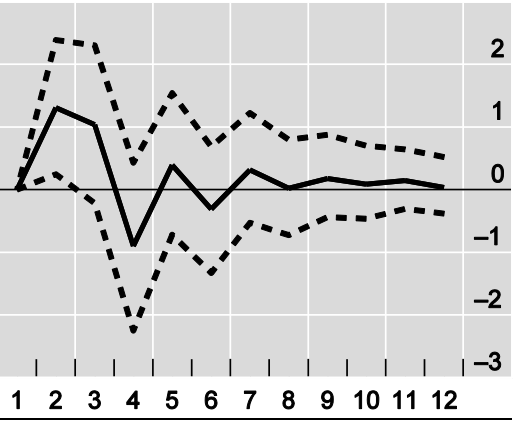

Malaysia

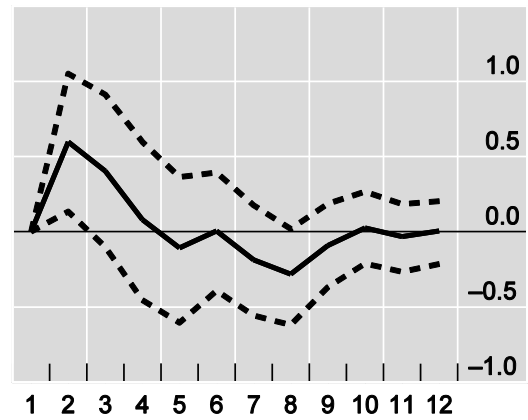

Thailand

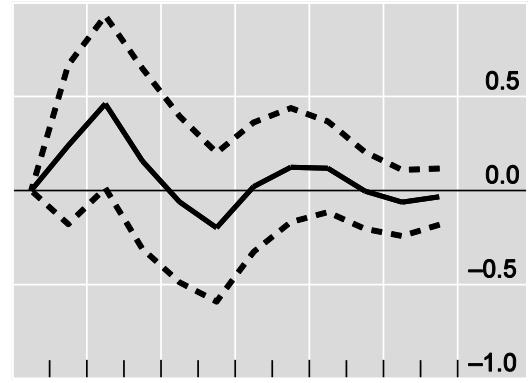

$\begin{array}{lllllllllllll}1 & 2 & 3 & 4 & 5 & 6 & 7 & 8 & 9 & 10 & 11 & 12\end{array}$

Vertical axis in per cent. Dashed lines display 80 per cent confidence bands.

The up-shot of declining pass-through is that the effectiveness of exchange rate control as a policy lever may be declining, for two reasons. First, declining pass-through implies a weakening link between exchange rate stability and inflation stability. To the extent that exchange rate movements are a source of macroeconomic volatility, less exchange rate pass-through decreases the domestic macroeconomic benefits from stabilising the exchange rate. And second, where exchange rates are actively used as a tool for domestic business cycle management to offset other shocks, if domestic prices fail to adjust, there will be little expenditure-switching in response to exchange rate changes. Adjusting the exchange rate in response to shocks in a low pass-through environment will have smaller effects on the demand for domestically produced goods than in a high pass-through environment. $^{8}$

8 If instead of focusing on the role of the exchange rate as a policy tool that can be used to influence the real economy we focus on its role as a price that adjusts in response to shocks, the logic reverses. As Devereux and Engel (2003) argue, the case for exchange rate flexibility rests in part on prices responding to exchange rates so as to stimulate expenditure switching. For a more general discussion of pass-through, see Burstein and Gopinath (2013). 
A second changing dynamic that may influence the role of the exchange rate is the ongoing integration of goods markets. Graph 2 illustrates the growth in trade volumes over time. One consequence of this is that consumption bundles are becoming increasingly similar across economies over time. As we will see, in our model, the mechanics of international risk sharing depend in part on the degree to which consumption bundles overlap between economies.

\section{Trade integration}

Imports plus exports of goods and services as a percentage of GDP

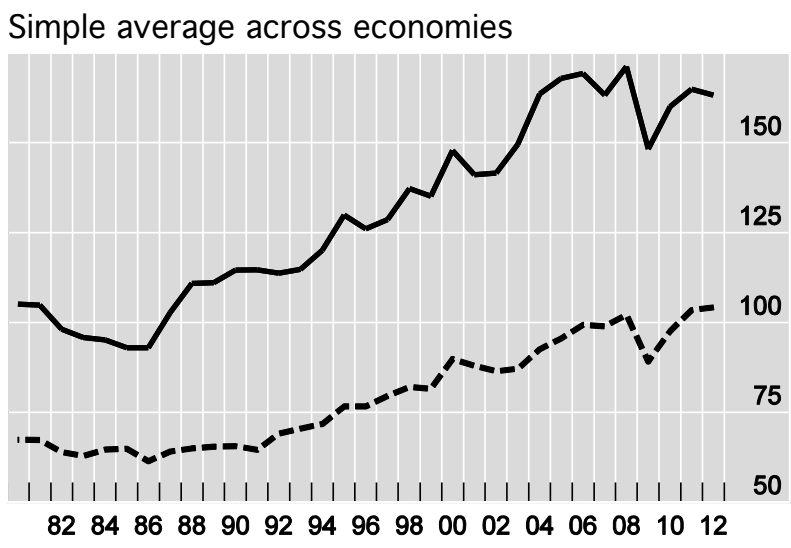

- Asia ex-Japan ${ }^{\mathrm{a}}$

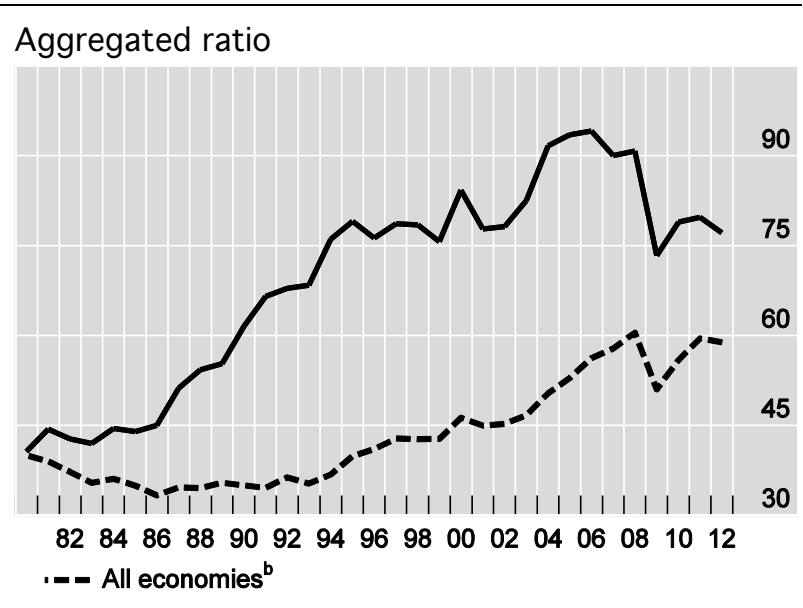

- All economies ${ }^{b}$

a China, Hong Kong SAR, India, Indonesia, Korea, Malaysia, Philippines, Singapore and Thailand. b 50 major economies.

Source: IMF World Economic Outlook, April 2013.

A third characteristic that may be important for the policy trade-offs that central banks face is increasing financial internationalisation. One simple metric of this is gross international investment positions, which have grown dramatically in recent years. As of end-2012, gross international positions as a share of GDP were at all-time highs for many regional economies.

One consequence of financial internationalisation is that international risk sharing is likely to be increasing. A standard test for risk sharing is to estimate an equation of the form:

$$
\Delta \log C_{i t}-\Delta \log C_{t}=\alpha_{i}+\beta_{t}\left(\Delta \log Y_{i t}-\Delta \log Y_{t}\right)+\varepsilon_{i t},
$$

where $C_{i t}\left(Y_{i t}\right)$ is real consumption (output) for economy $i$ and $C_{t}\left(Y_{t}\right)$ is world real consumption (output) in period $t$, where all variables are measured in per capita terms. ${ }^{9}$ The estimate of $\beta_{t}$ is a measure of risk-sharing, with $\beta_{t}=0$ implying full risk-sharing.

While the international evidence of increasing risk sharing using this approach reported elsewhere tends to be limited, we find strong evidence for growing risk-sharing for economies in Asia. Graph 3 plots panel estimates of $\beta$, together with $95 \%$ confidence bands based on robust standard errors, for the nine economies displayed in Graph 1, on 15-year rolling samples, for four different specifications: one-year, five-year and ten-year differences in consumption and output, and in levels. Clearly there has been a noticeable decline in the estimates over the sample in all cases, consistent with increasing risk-sharing.

9 See, for example, Bai and Zhang (2012) and Kose et al (2009). As is common in this literature, we use data from Penn World Tables 8.0 to construct consumption and output measures per capita to estimate this equation. In computing global measures, we include all 107 economies that are present in the dataset no later than 1960. 


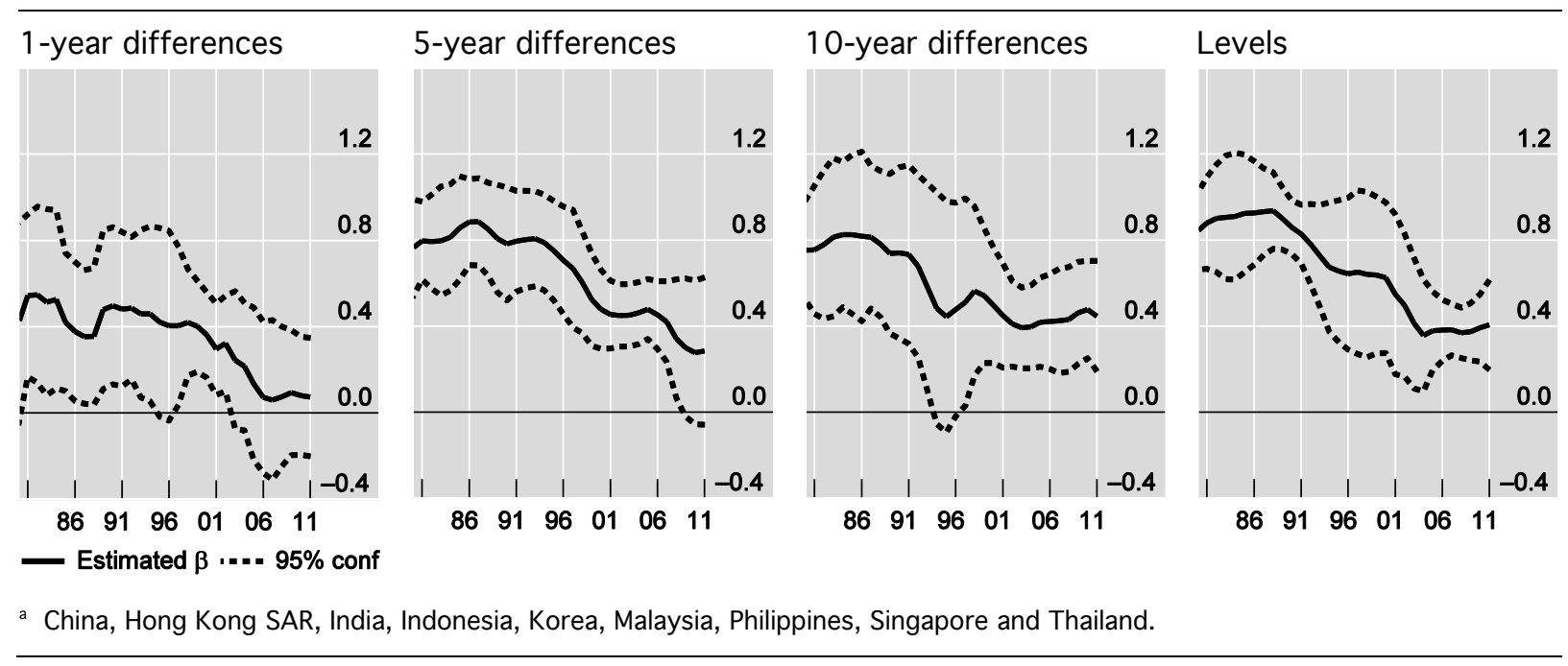

Devereux and Sutherland (2008) examined whether increased international asset positions in themselves influence optimal monetary policy. After all, when international positions are large, exchange rate movements may have considerable wealth effects. However, they show that when large asset positions are the result of efficient portfolio choices, exchange rate movements are an important ingredient in ensuring the optimal sharing of risk. Thus large international positions per se do not support the need for exchange rate stability.

More generally, our graphical evidence is suggestive that the economies in emerging Asia are increasingly internationalised and integrated into global financial markets. One practical implication of this is that the scope for policymakers to use sterilised foreign exchange intervention to stabilise exchange rate movements may be becoming more limited. Indeed, in the limit, if financial markets are fully integrated and asset markets are complete, then the implications of the policy trilemma are likely to become stark, as we will show.

While efficient markets and full risk sharing are unlikely in reality, the underlying principle of reduced effectiveness of foreign exchange intervention as financial internationalisation increases is likely to be a practical constraint on policymakers' actions. Effectively, central bankers may still be able to influence exchange rates as financial internationalisation increases, but not without having to sacrifice some degree of domestic monetary control. In practical terms, as we will later model, increased financial openness reduces the possibility of sterilised intervention - where the exchange rate can be controlled without changing domestic interest rates - while leaving open the possibility of unsterilised intervention. ${ }^{10}$

Taking all our arguments together, there is increasing evidence that some of the historical motivations for what have lain at the heart of the so-called "fear of floating" (Calvo and Reinhart, 2002) have declined. Decreased exchange rate pass-through and ongoing goods and financial market internationalisation may now allow for a reassessment of the importance of exchange rate stability in achieving monetary policy goals. In Section 4, we will develop an analytical model to address this question. But first, we discuss current central bank responses to exchange rate movements in Asia.

\section{Policy responses to exchange rates}

In many Asian economies, a common policy response to exchange rate fluctuations has been foreign exchange intervention, intended to smooth the path of exchange rates. Mohanty and Klau (2004)

10 Just as improved inflation performance may lead to declining exchange rate pass-through (Devereux and Yetman 2010), improved inflation performance may encourage increased financial internationalisation. Devereux et al (2013) show that a monetary policy rule which reduces inflation variability leads to an increase in the size of gross external positions, both in equity and bond portfolios, consistent with increased financial globalisation. 
found that some emerging market economies respond more strongly to exchange rate movements than to either inflation or the output gap. Filardo et al (2011) provided a summary of how emerging market economy central banks respond to exchange rates and reported that central banks managed the value of their currencies more actively in the aftermath of the international financial crisis than before.

One consequence of attempts to manage exchange rates has been the massive expansion of foreign exchange reserves on central bank balance sheets in the region over the past decade. The overall size now lies at around $100 \%$ of GDP for Hong Kong and Singapore, and more than $30 \%$ of GDP for China, Korea, Malaysia, the Philippines and Thailand, and changes in foreign exchange reserves account for nearly all of the increase over the past decade (Graph 4).

\section{Change in composition of central bank assets in Asia, 2002-12}

As a percentage of change in total assets

Graph 4

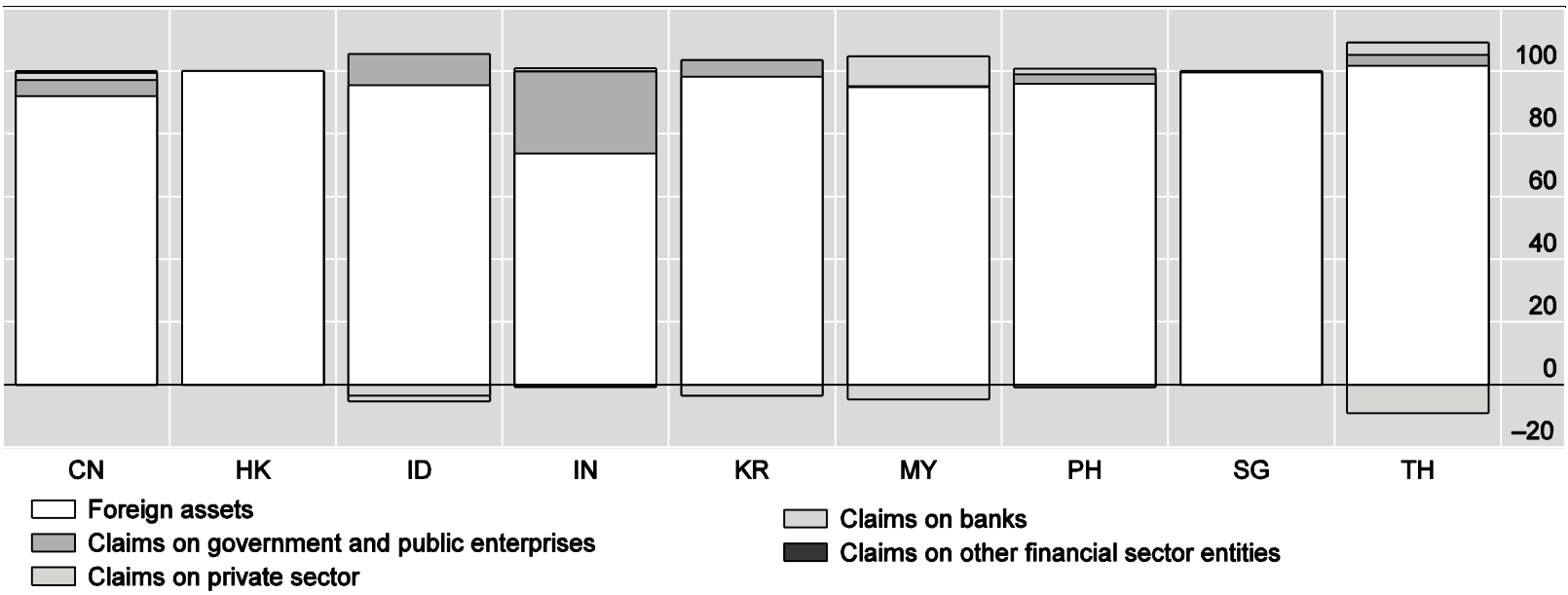

$\mathrm{CN}=$ China; HK = Hong Kong SAR; ID = Indonesia; IN = India; KR = Korea; MY = Malaysia; PH = Philippines; SG = Singapore; TH = Thailand.

Source: IMF International Financial Statistics.

Change in composition of central bank liabilities in Asia, 2002-12

As a percentage of change in total liabilities

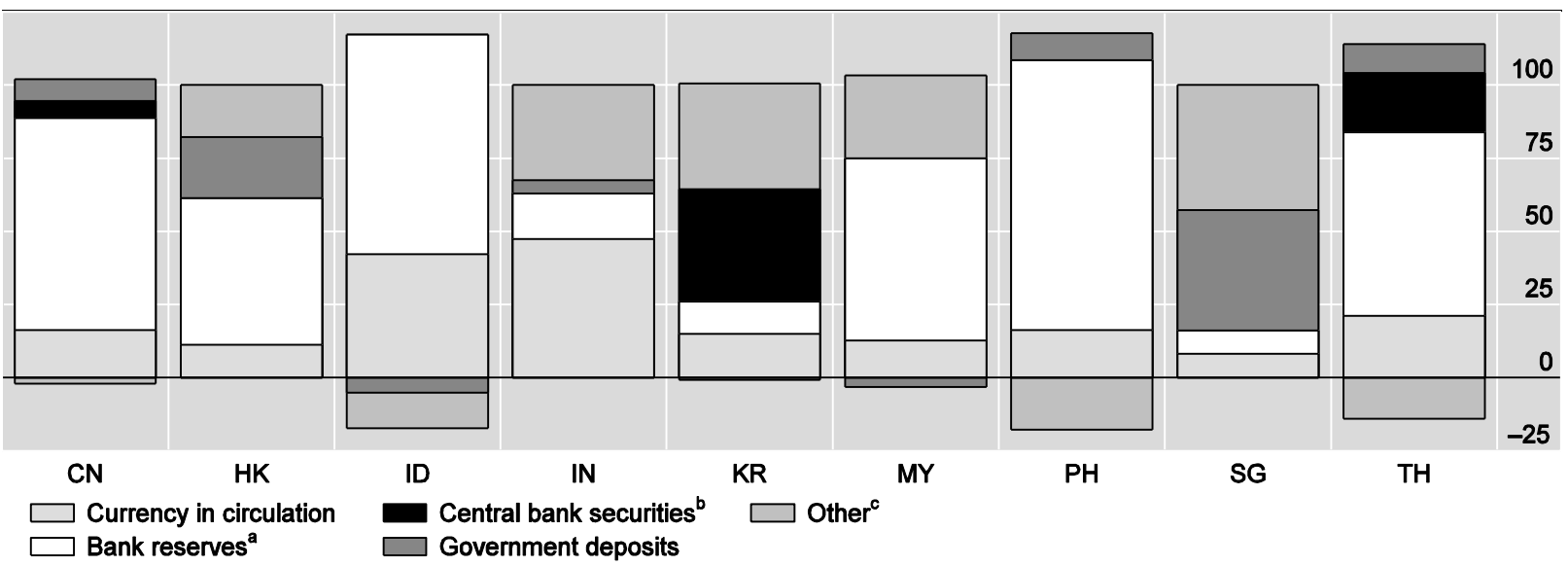

$\mathrm{CN}=$ China; HK = Hong Kong SAR; ID = Indonesia; IN = India; KR = Korea; MY = Malaysia; PH = Philippines; SG = Singapore; TH = Thailand.

a Reserves and deposits of banks. b Central bank bonds and securities. c Including other liabilities (foreign liabilities, loans and other net items) and equity capital.

Source: IMF International Financial Statistics. 
Turning to the liabilities side of the balance sheet, only a small portion of the increase in foreign exchange reserves has been financed via an increase in the amount of currency in circulation (Graph 5). Instead, increased required reserves and the issuance of sterilisation instruments have been used to effectively sterilise the effects of the increase in foreign exchange reserves, allowing policymakers to maintain domestic monetary control. ${ }^{11}$

Going forward, one possibility would be for policymakers to continue with past practice, and offset any on-going exchange rate pressures with intervention. However, there are at least two reasons why this may be becoming a less attractive policy option. First, as we have argued above, Asia is becoming more financially internationalised. Thus attempts to intervene in foreign exchange markets are increasingly likely to be offset by other market participants, so that policy measures fail to have their desired effect on exchange rates. Second, the already large holdings of foreign exchange reserves are very costly to the central banks in the region, and are only likely to become more so if reserves grow larger, as would occur if appreciation pressures remain dominant.

Table 1 illustrates the possible costs of large reserves under the simplifying assumption that all reserves are held in short term US treasury bills and are financed (or, equivalently, sterilised) via the sale of short term sterilisation bills with an interest cost equal to the domestic deposit rate. One cost component is carrying (or sterilisation) costs. Typically, domestic interest rates in Asia are higher than the yields earned on foreign exchange reserves. The difference between these two is a loss to the central bank, and may be as much as $1.2 \%$ of GDP per year for some economies. Another potentially cost is mark-to-market losses from currency appreciation; for illustrative purposes, the table considers a $10 \%$ appreciation. The table also displays central bank equity, again as a per cent of GDP, which is available to absorb these losses. While a central bank can in principle continue to operate with low, or even negative, capital, this is unlikely to be desirable in the long run. More importantly, any loss on the central bank's balance sheet that results from excessive foreign exchange reserves may be viewed as representing a welfare loss to society. ${ }^{12}$

\section{An open economy model}

We now outline a simple model consisting of two economies, home and foreign. While we conduct an essentially theoretical exercise, we intend it to inform the discussion and conduct of policy-making in the set of Asian economies discussed previously. In line with this objective, where possible we follow a model calibration based on measurements taken from previous DSGE models applied to Asian economies. The model is a standard New Keynesian DSGE framework, with a mixture of producer currency pricing and local currency pricing and home bias. ${ }^{13}$ We add one new element to the model, meant to capture variation in the degree of financial market integration, based on Devereux and Yetman (2014). This is represented by the following equation: ${ }^{14}$

$$
\left[\left(\frac{C_{t}^{-\sigma}}{C_{t}^{*-\sigma}}\right)\left(\frac{S_{t} P_{t}^{*}}{P_{t}}\right)\right]^{\lambda}\left[\frac{\bar{P}_{t} Y_{t}-\Delta\left(F R_{t}\right)}{P_{t} C_{t}}\right]^{1-\lambda}=1 .
$$

In this equation $\lambda$ represents the degree of international financial integration. If $\lambda=1$, then the equation represents the usual state-by-state condition for complete financial markets (perfect

\footnotetext{
11 See the discussion in Filardo and Yetman (2012). Aizenman and Glick (2009), Cavoli and Rajan (2006) and Ouyang and Rajan (2011) also find that sterilisation is close to complete in Asian economies.

12 See also the discussion in Cook and Yetman (2012).

13 The model is similar to Engel (2011, 2013 and 2014). For full model details, see the appendix.

14 Devereux and Yetman (2014) show that this condition can be derived based on a tax on the financial returns from investing in foreign assets which takes the form $\left(1+t_{t}\right)=\left(P C_{t} /\left(\bar{P}_{t} Y_{t}-\Delta(F R)\right)\right)^{(1-\lambda) / \lambda}$. Independently, Catão and Chang (2013) considered an equivalent functional form (excluding a role for foreign exchange reserves) in their investigation in the optimal monetary policy response to food prices.
} 
international risk-sharing) and full financial integration. ${ }^{15}$ If $\lambda=0$, then there are no private financial markets across economies at all and each economy consumes its income period-by-period, adjusted for the change in the stock of foreign exchange reserves $(F R)$. We can vary $\lambda$ between 0 and 1 to allow for an arbitrary degree of financial market integration and study the policy implications of increasing financial openness in Asian economies, in line with the evidence on increased risk-sharing documented in Section 3. Because foreign exchange reserves enter the model only through the second bracketed term in condition (2), it is clear that the effectiveness of foreign exchange reserves as a policy tool (i.e. sterilised intervention) will depend critically on the level of financial internationalisation. In particular, in the limit, as $\lambda \rightarrow 1$, a change in foreign exchange reserves will have no effect on exchange rates.

\section{Estimates of sterilisation costs and valuation losses from currency appreciation}

As of December 2012

Table 1

\begin{tabular}{|c|c|c|c|c|c|}
\hline & $\begin{array}{l}\text { FX reserves } \\
\text { (USD billions) }\end{array}$ & $\begin{array}{l}\text { Short-term } \\
\text { rate }(\%)\end{array}$ & $\begin{array}{c}\text { Central bank } \\
\text { equity }{ }^{\mathrm{a}, \mathrm{b}}\end{array}$ & $\begin{array}{c}100 \% \\
\text { sterilisation } \\
\text { cost }^{a, c}\end{array}$ & $\begin{array}{c}\text { Valuation loss for a } \\
\text { 10\% appreciation of } \\
\text { domestic currency } \\
(\%)^{\mathrm{a}}\end{array}$ \\
\hline China & 3331.12 & 3.78 & 0.04 & 1.11 & 4.04 \\
\hline Hong Kong SAR & 317.23 & 0.40 & 31.17 & -0.31 & 12.30 \\
\hline India & 270.59 & 8.74 & 0.07 & 0.73 & 1.39 \\
\hline Indonesia & $106.04^{d}$ & 4.92 & 2.02 & $0.64^{d}$ & $1.18^{d}$ \\
\hline Korea & 323.21 & 2.89 & 0.88 & 0.90 & 2.81 \\
\hline Malaysia & 137.75 & 3.21 & 0.01 & 1.22 & 4.48 \\
\hline Philippines & 73.48 & 0.83 & 0.55 & 0.89 & 3.05 \\
\hline Singapore & 259.09 & 0.31 & 20.49 & -0.12 & 9.67 \\
\hline Thailand & 173.33 & 2.93 & 2.61 & 0.98 & 4.60 \\
\hline
\end{tabular}

a As a percentage of nominal GDP. ${ }^{b}$ Provisions and other liabilities for SG; net worth or own capital for others. c Assumes entire FX reserve is invested in 1-3 year US government bonds and the funding rate is the domestic deposit rate. d As of September 2012.

Sources: IMF IFS; Bloomberg; Datastream; BIS calculations.

We combine condition (2) with a standard New Keynesian open-economy model with the following features. We allow for home bias in consumption. In particular, let the home economy consumption index be defined over home and foreign good consumption as follows:

$$
C=\left(C_{H}\right)^{v / 2}\left(C_{F}\right)^{1-v / 2} .
$$

The parameter $v$ captures the degree of openness to goods trade discussed in Section 3: $v=1$ corresponds to the absence of home bias, and $v=2$ to complete home bias such that there is no overlap in the consumption bundles of the two economies. We also allow for a portion $\delta$ of imported goods to be priced in the consumers' currency and the remainder in the producers' currency, as in Berka et al (2012). As we outlined in Section 3, short-run exchange rate pass-through appears to have declined in Asia, so that the link between exchange rate and inflation changes has weakened. We

15 Here, $C$ is home consumption, $C^{*}$ is foreign consumption, $S$ is the nominal exchange rate, and $P$ and $P *$ represent the home and foreign CPIs. In addition, $\bar{P}$ is the home GDP deflator and $Y$ is home GDP. 
model this analytically by assuming that a greater portion of imported goods are now priced in the consumers' currency rather than the producers' currency. ${ }^{16}$

We allow the policymaker to respond to exchange rate changes in one of two ways. First, we assume that home economy interest rates can respond to the change in the nominal exchange rate in addition to $\mathrm{CPI}$ inflation. One may think of this as being a form of unsterilised foreign exchange intervention, since interest rates are affected by policy actions intended to influence exchange rates. Second, we allow policymakers to intervene directly in foreign exchange markets by adjusting foreign exchange reserves in response to changes in the nominal exchange rate. This will directly affect the solution to equation (2) above. We assume that:

$$
\Delta(F R)_{t}=\left(S_{t-1} / S_{t}\right)^{\chi}
$$

For $\chi>0$, an appreciation of the domestic currency precipitates a build-up of foreign exchange reserves. With $\lambda<1$, this represents a policy of sterilised intervention since interest rates are not directly affected by policy actions that influence the exchange rate.

There are few existing papers that model sterilised intervention in a comparable manner. One exception is Benes et al (2013). ${ }^{17}$ They also allow for two different monetary policy responses to exchange rates, including both interest rate responses and sterilised foreign exchange intervention. But their modeling of the latter differs from ours: they assume that foreign exchange intervention works through a portfolio balance effect to influence endogenous interest rate spreads, and hence exchange rates.

A number of papers look at the interaction between capital controls and sterilised intervention. Prasad (2013) shows that capital controls and sterilised intervention, used together, can be welfare-improving by offering the central bank an additional policy tool. The combination of these two tools allows authorities to effectively choose the level of foreign bond holdings. Since households do not take account of the effect of their foreign bond-buying decisions on prices, and the central bank can, the ability to control holdings of foreign bonds can be welfare enhancing. Bacchetta et al (2013) consider the optimality of capital controls and the accumulation of foreign exchange reserves. They show that, if households face a borrowing constraint but the authorities do not, one way to improve domestic welfare outcomes is to adjust interest rates away from world levels, which requires the imposition of capital controls. Variation in the level of foreign exchange reserves can also then be used to influence the trade balance. In contrast to these papers, we take the degree of financial internationalisation (including the use or absence of capital controls) as given and compare the effectiveness of sterilised intervention versus unsterilised intervention in pursuit of policy goals. ${ }^{18}$

We evaluate the welfare effects of following different monetary policy rules based on a second-order approximation to the welfare function, in the spirit of Woodford (2003). As in Engel (2011), this welfare function depends on the output gaps (that is, output relative to where it would be if prices were flexible), inflation rates and exchange rate misalignments. As in almost all of the literature on optimal monetary policy in New Keynesian open economy models, we abstract away from strategic considerations to focus on the cooperative policy that maximises global welfare. A full exploration of monetary policy in a non-cooperative framework involves considerable technical and conceptual difficulties and would take us beyond the scope of the present paper. For example, in a strategic setting, the choice of strategy space is important; there may be many equilibria, indexed by threats or

16 One limitation of our two-economy model is that we cannot incorporate "vehicle currency pricing", discussed in Goldberg and Tille (2008) and Cook and Devereux (2006), whereby an economy sells goods to its trading partners priced in a third economy's currency, for example when Asian economies trade with each another based on US dollar pricing.

17 See, also, Ostry et al (2012) who construct a reduced-form linear model where sterilised intervention and interest rates are used to minimise a quadratic loss function in the output gap, inflation, the exchange rate and the stock of reserves.

18 An alternative role for foreign exchange intervention and the accumulation of reserves, aside from the one that we consider here, is to maintain an undervalued exchange rate to spur higher rates of economic growth. For example, Korinek and Servén (2009) show how an undervalued exchange rate, which raises the price of tradable goods relative to non-tradables, may be desirable if the tradable sector is more capital intensive if there are sufficient learning-by-doing externalities in the economy. 
trigger strategies; and each policy-maker will typically attempt to manipulate its terms of trade in its favour, introducing an additional distortion into the analysis. ${ }^{19}$

The full model and its log-linearisation are outlined in the appendix. The model is quite sparse, relative to some of the recent DSGE models used in the literature, but, as we have noted above, it is designed to highlight three key margins of structural change in Asian economies. These are captured by the parameters $\lambda, v$ and $\delta$, for the degree of financial integration, goods market integration and short run exchange rate pass-through into consumer prices respectively. From the estimates given in Graph 3 , it is clear that the appropriate value for $\lambda$ is between 0 and 1 and declining; we explore the impact of variations in $\lambda$ on optimal policy below. The higher is the $v$ parameter, the more the economy is closed to international trade, with $v=1$ capturing complete openness. For the nine major Asian economies discussed in Section 2, the median exports/GDP ratio is increasing and was 0.58 in 2012. Taken literally, this would correspond to a $v$ parameter less than unity in a symmetric steady state (since exports/GDP will be $(1-v / 2)$ in this case). But measured exports include a lot of intermediate goods, so $v>1$ is likely to be the more relevant empirical case. Finally, the closer $\delta$ is to unity, the lower is the value of short-run pass-through. The estimates in Graph 1 would imply a very high value of $\delta$. Note, however, that $\delta$ only captures the immediate impact effect of exchange rate passthrough, while the full dynamics of pass-through in the model are captured by the shock process and the degree of price rigidity.

We also consider two shocks, productivity and markup shocks, with parameterisations that are similar to those in the literature that has employed DSGE modelling for Asian economies (e.g. Wong et al 2014). The degree of price adjustment follows a Calvo-type specification, and again is calibrated along lines used in previous applications for Asia. A full set of variable and parameter names, descriptions and calibrated parameter values is given in Table 2.

\section{Results}

We now examine the results of our model, focusing on how sterilised or unsterilised foreign exchange intervention can be used to improve welfare. We compute the maximum achievable level of global welfare under four different assumptions about how monetary policy is set. First, monetary policy is characterised by a simple Taylor-type rule, where interest rates in both economies respond linearly to domestic CPI inflation (labelled "Taylor" in the graphs that follow). Second, monetary policy is characterised by a Taylor-type rule, but where interest rates in the home economy also respond to the change in the nominal exchange rate ("Taylor + unsterilised"). Third, monetary policy is characterised by a Taylor-type rule in inflation in both economies, but the home monetary authority can also use sterilised intervention, where the change in foreign exchange reserves is a linear function of the change in the nominal exchange rate in log terms ("Taylor + sterilised"). Finally, we also compute the optimal Ramsey outcome, where the responses of interest rates in both economies, and the change in foreign exchange reserves in the home economy, are chosen so as to maximise global welfare, as a reference point against which to compare the other results. ${ }^{20}$

We consider productivity shocks and cost-push shocks in turn. In each case, both economies are subject to independent shocks that have AR(1) persistence coefficients of 0.9 . We then examine the relative performance of the different monetary policy regimes across three different dimensions:

19 For examples of papers that examine strategic considerations in more restrictive environments than ours, see Benigno and Benigno (2006) who derive the welfare approximations in a two economy setting with producer currency pricing and complete financial markets, but do not solve for the non-cooperative optimal monetary policies. Clarida, Gali and Gertler (2002) solve a simpler problem where optimal subsidies are in place to offset the terms of trade distortion, assuming complete financial markets. Cook and Devereux (2013) employ an extended version of the Clarida, Gali and Gertler specification to solve a non-cooperative policy problem in a zero-bound environment where only one policy-maker is choosing monetary policy optimally.

20 The first three of these are solved using the "optimal simple rules" routine in Dynare, and the final one using the "Ramsey policy" routine. 
- Varying the degree of international risk-sharing, or financial internationalisation, as captured by the parameter $\lambda$;

- Varying the degree of short-run exchange rate pass-through, as captured by the parameter $\delta$

- Varying the degree of goods market integration, captured by the parameter $v$.

Variables and parameters

Table 2

\begin{tabular}{|l|l|l|l|l|}
\hline Names & Description & Name & Description & Value \\
\hline$c$ & Consumption & $\sigma$ & Inverse of elasticity of inter-temporal substitution & 2.0 \\
\hline$p$ & Price level & $v$ & Home bias in consumption & $1-2$ \\
\hline$s$ & $\begin{array}{l}\text { Nominal exchange } \\
\text { rate }\end{array}$ & $\theta$ & $\begin{array}{l}\text { Elasticity of substitution between different } \\
\text { varieties of home (foreign) goods }\end{array}$ & 11.0 \\
\hline$y$ & Output & $\delta$ & Share of imports that are LCP (remainder are PCP) & $0-1$ \\
\hline$\tau$ & Terms of trade & $\lambda$ & Degree of financial internationalisation & $0-1$ \\
\hline$\Delta$ & $\begin{array}{l}\text { Deviation from law } \\
\text { of one price }\end{array}$ & $\chi$ & $\begin{array}{l}\text { Response of foreign exchange reserves to nominal } \\
\text { exchange rate changes }\end{array}$ & $0-\infty$ \\
\hline$f r$ & $\begin{array}{l}\text { Foreign exchange } \\
\text { reserves }\end{array}$ & $\beta$ & Discount rate & 0.99 \\
\hline$u$ & Cost-push shock & $\kappa$ & Degree of price stickiness & 0.075 \\
\hline$a$ & Productivity shock & $\phi$ & Elasticity of labour supply & 1.0 \\
\hline$V$ & Welfare & $\zeta$ & Interest rate response to inflation & $0-\infty$ \\
\hline & & $\gamma$ & $\begin{array}{l}\text { Home interest rate response to the change in } \\
\text { exchange rates }\end{array}$ & $0-\infty$ \\
\hline
\end{tabular}

Graph 6 illustrates the effectiveness of different policy rules in achieving optimal welfare in response to productivity shocks. The horizontal axis is the proportion of imports that are priced in the local currency, $\delta$. The left-hand panel is under financial autarky $(\lambda=0)$, and the right-hand panel with complete financial internationalisation $(\lambda=1)$. In-between levels of financial internationalisation are qualitatively similar to the autarky case. In this exercise, there is some home-bias in consumption $(v=1.5)$. Note that all welfare levels are relative to the Ramsey outcome: a welfare level of zero indicates that welfare is the same as would result from the Ramsey policy.

With less-than-complete financial internationalisation, a combination of sterilised intervention and following a simple Taylor rule, where the coefficient is chosen optimally, comes closest to achieving the optimal Ramsey outcome. However, there is little substitutability between sterilised and unsterilised intervention. This is because any improvement in outcomes with unsterilised intervention is the result of a trade-off: a single policy instrument (interest rates) is being used to respond to an additional variable. In welfare terms, that trade-off is barely worth making: the paths of all nominal and real variables are little changed whether the central bank responds only to inflation or to both inflation and exchange rate changes optimally. In contrast, sterilised intervention represents an additional policy tool that does not compromise the interest rate response to inflation. We can see these effects by looking at the impulse responses. Graph 7 outlines the responses to a domestic productivity shock with financial autarky, home bias and a mixture of local currency and producer currency pricing. Three different policy rules are considered, corresponding to each of the optimal policy rule parameters displayed in the previous graph. 
Welfare effects of productivity shocks

Home bias $(v=1.5)$

Graph 6

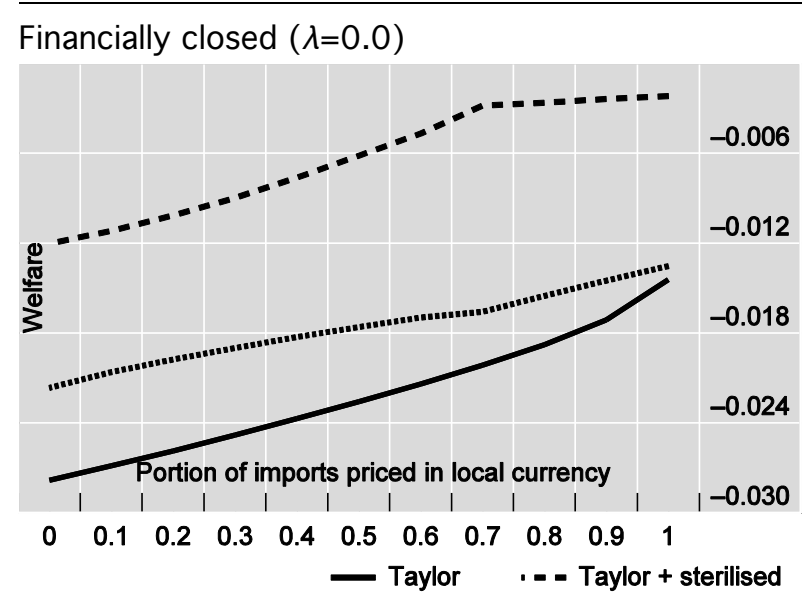

Financially open $(\lambda=1.0)$

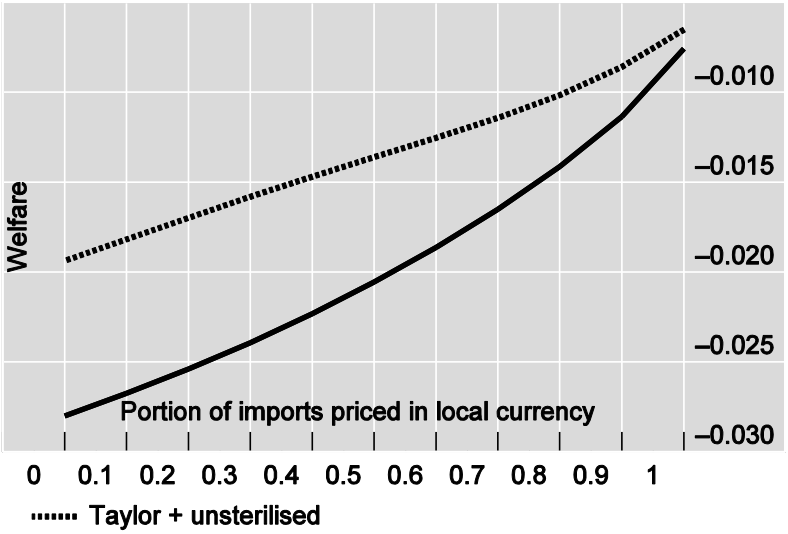

All outcomes are relative to the Ramsey policy.

Impulse responses to domestic productivity shock

$\lambda=0.0, \delta=0.5, u=1.5$

Graph 7

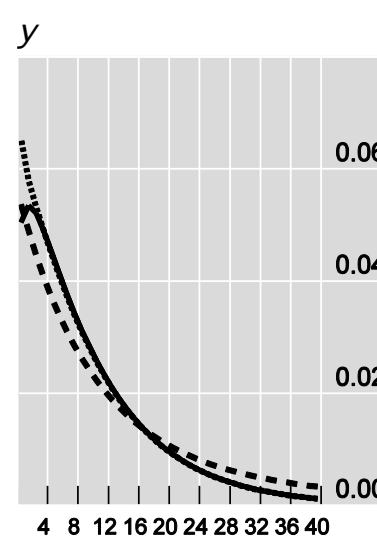

$y^{*}$

$\tau$

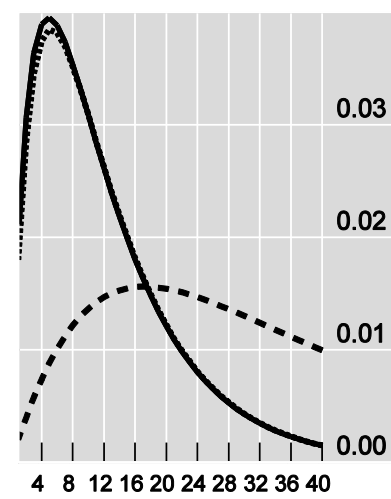

- Taylor

$\Delta$

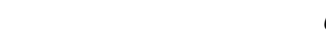

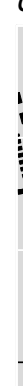

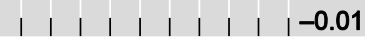

481216202428323640

| $|1||||||||| 1-0.03$

481216202428323640 $s-s(-1)$

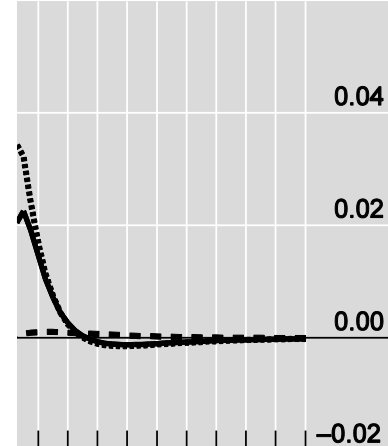

481216202428323640

- - - Taylor + sterilised

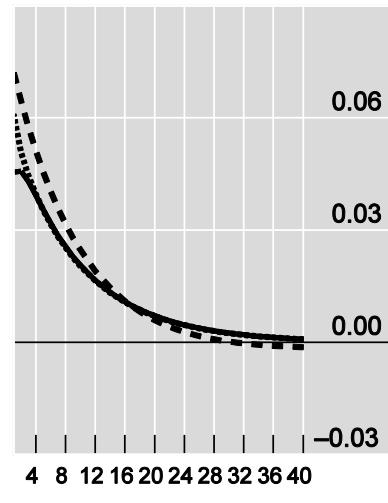

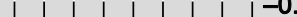

481216202428323640

....... Taylor + unsterilised

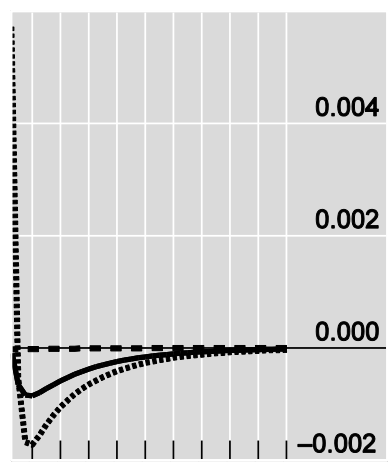

481216202428323640

$c^{*}$

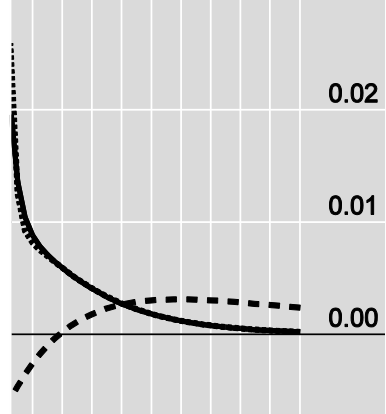

| | | | | | | | | | | | | | $1-0.01$

481216202428323640

$\pi$

.004

0.002

.000 
A home economy productivity shock is deflationary for the home economy. The optimal Taylor rule response is a reduction in policy rates, which leads to an exchange rate depreciation, and a corresponding reduction in the price of the home good for foreign consumers. Effectively, the behaviour of the exchange rate here is helping to compensate for the lack of international risk sharing. Households in the foreign economy do not hold home-economy assets, so the only way they can share in the benefits of a home-economy productivity shock is if the price of home-economy goods falls. Hence a deviation in the law of one price can be consistent with maximising global welfare in a world in which monetary policy is constrained to follow a Taylor rule.

Amending the interest rate rule to allow for an optimal linear policy response to exchange rate changes (in log terms), in addition to the response to domestic inflation, allows for a more precisely calibrated policy response along the same lines. The response to the exchange rate entails a sharp reduction in policy rates, sufficient to fuel a low level of inflation in the domestic economy on impact and increase the deviation from the law of one price. Qualitatively, the consumption path across the two economies is more alike with this more complex rule.

Including sterilised intervention instead, we can see that the use of this new, independent, policy instrument completely changes the responses of the economy under optimal policymaking. The central bank now responds very strongly to domestic inflation using interest rates and to the exchange rate using sterilised intervention. The result is that the response of exchange rates and prices (and therefore also deviations from the law of one price) are all effectively eliminated. However, whereas consumption increased in both economies in response to a positive domestic economy productivity shock before, now consumption in the foreign economy actually declines on impact. To understand how this can represent an optimal policy response, initial consumption falls, but long-term consumption rises. Combining these, the discounted lifetime welfare for foreign consumers is only slightly lower using sterilised intervention than with only a Taylor rule response. And, from the perspective of global welfare, this is more than offset by the gain to domestic economy consumers, who now see a larger increase in consumption in response to the productivity shock.

The availability of sterilised intervention gives monetary authorities an additional policy tool that is not available in the fully integrated financial markets case. It effectively allows for income or wealth transfers across economies in response to shocks in ways that can assist the goal of overall stabilisation policy. In the case of Graph 7, in the absence of sterilised intervention, the home economy productivity shock will generate a terms-of-trade deterioration, and a persistent increase in home output relative to foreign output. For a given response of the world output gap, it is inefficient to have the home output gap differ from the foreign output gap. Sterilised intervention can correct this, by generating a reversal in the response of the terms of trade, and a fall in foreign consumption. The joint effect of both of these movements is to maintain a higher level of foreign output. At the same time, sterilised intervention acts so as to limit the response of the nominal exchange rate to the shock and, by doing so, reduces the inefficiencies associated with deviations from the law of one price.

In a world of complete financial integration (Graph 6, right panel), sterilised intervention is no longer effective. Instead, the only avenue for policymakers to influence the exchange rate is through unsterilised intervention. Then they cannot get as close to Ramsey outcome, conditional on the level of financial internationalisation.

Graph 8 repeats the same exercise as in Graph 6, but with the degree of short-run exchange rate pass-through fixed such that half of imports are priced in the producer currency, and half in the local currency $(\delta=0.5)$. Instead, the degree of goods market integration is varied from $v=1.9$ (goods markets are almost closed) to $v=1.0$ (no home bias in consumption). The horizontal axis - goods market integration - is defined as $(2-v)$ so that a higher number corresponds with greater integration. All welfare measures are again relative to those under the Ramsey policy. Note that the levels of welfare across different values of goods market integration are not directly comparable, since $v$ is a preference parameter. Instead, the purpose of the exercise is to focus on the relative performance of the different policy measures at given levels of goods market integration.

With high levels of home bias sterilised intervention is an especially potent tool for achieving close to the first-best outcome. Without sterilised intervention, a positive domestic productivity shock would cause the domestic currency and terms of trade to depreciate, distorting consumption decisions. Sterilised intervention can be used to prevent this. 


\section{Welfare effects of productivity shocks}
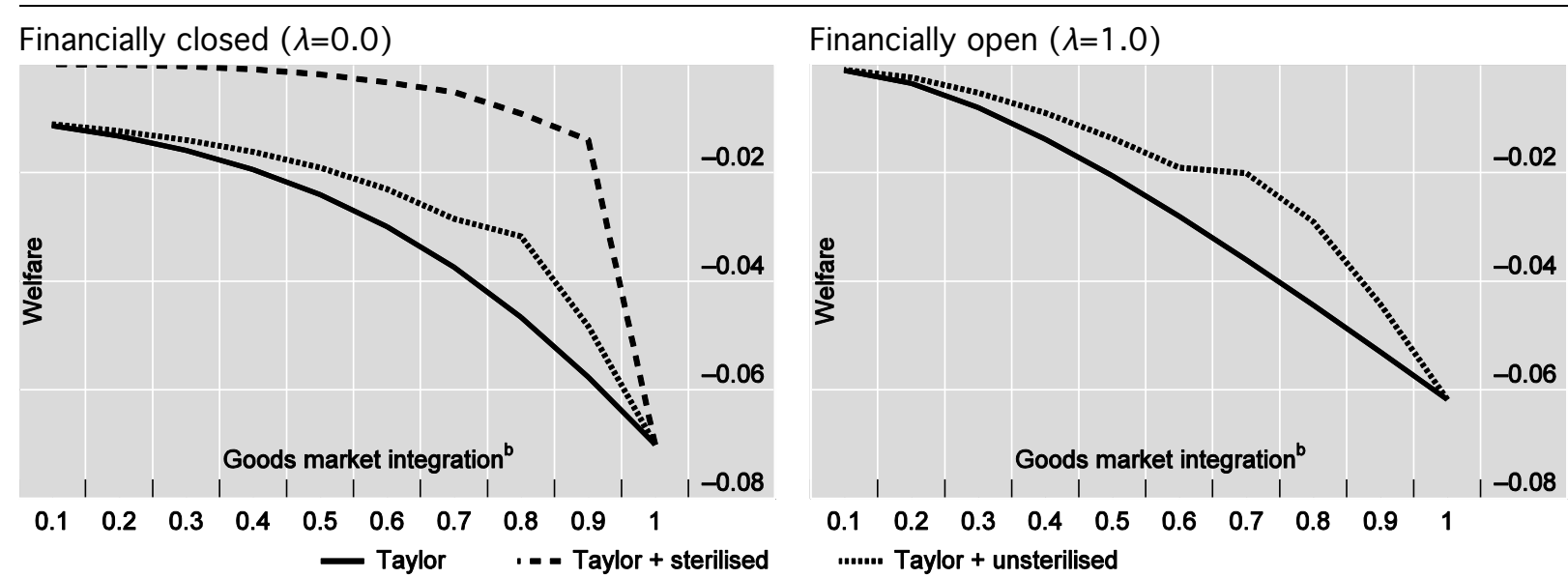

${ }^{a}$ Half of all import varieties are assumed to be priced in the local currency and half in the producer currency. $\mathrm{b}$ Goods market integration is defined as 2- $v$.

The effectiveness of sterilised (and unsterilised) intervention in response to productivity shocks relies on some degree of home bias. In the limit of no home bias in consumption, provided the monetary policy response to inflation is optimal, there are no gains to intervening in foreign exchange markets in response to productivity shocks. (This is true independent of the degree of exchange rate passthrough and financial internationalisation). The optimal response to inflation via the Taylor rule is sufficient to fully stabilise inflation and, when consumers in both economies have identical preferences over both home and foreign goods, also fully stabilise the nominal exchange rate. Given that inflation and the exchange rate are fully stabilised, deviations from the law of one price and the welfare costs of nominal rigidities are entirely eliminated. Effectively, goods market integration serves as a means of risk sharing in response to productivity shocks; in the limit of complete goods market integration, it emulates complete risk-sharing. Hence, with complete goods market integration, there are no gains to a monetary policy rule that entails a response to the exchange rate over one that simply responds to inflation.

More generally, if goods markets are not fully integrated, then even if inflation in both economies is stabilised, the price of imported goods will tend to behave differently from the price of domestically produced goods, and the exchange rate will vary in response to productivity shocks. In that case, sterilised intervention can be effective.

In the following two graphs we repeat the analysis for a cost-push shock, across the same dimensions as above. The results are broadly similar.

One interesting outcome across all our results is the relative unimportance of the degree of financial internationalisation. Visually, for all levels of $\lambda<1$, the graphs look similar to the financially closed ( $\lambda=0$ ) case presented in the left-hand panels of the graphs above. As $\lambda$ increases, provided it remains below 1.0, there is little impact on achievable welfare. But once we move to a world of perfect financial internationalisation, then, by construction, sterilised intervention no longer plays a role.

One limitation in this interpretation of our results is that we do not capture the potential costs of volatile reserves in our model. As the level of financial internationalisation increases, but remains incomplete, central banks are able to achieve exactly the same outcome with ever increasing foreign exchange intervention. But this implies that the volatility of foreign exchange reserves is increasing in the level of financial internationalisation.

Clearly policymakers ascribe a negative welfare impact to highly volatile foreign exchange reserves. More volatile reserves implies an increased likelihood of extremely high levels of reserves, leading to increased risks on the central bank's balance sheet and high sterilisation costs as discussed in Section 3, or completely running out of reserves and having no choice but to change the monetary policy regime. While explicitly modelling the cost of volatile reserves is beyond the scope of this paper, 
we address this issue by adding an additional term to the welfare function of $\left(f r_{t}-f r_{t-1}\right)^{2}$, in log terms, with a weight of negative one. In Graph 11 we present analogous results to those presented previously in Graph 6 for a range of levels of financial internationalisation, but incorporating this negative welfare effect of foreign reserves volatility. This has the intuitive effect of lowering the gains available from pursuing sterilised intervention, such that unsterilised intervention dominates sterilised intervention long before the economies are fully financially internationalised. ${ }^{21}$

\section{Welfare effects of cost-push shocks}

Home bias $(v=1.5)$

Graph 9

\section{Financially closed $(\lambda=0.0)$}

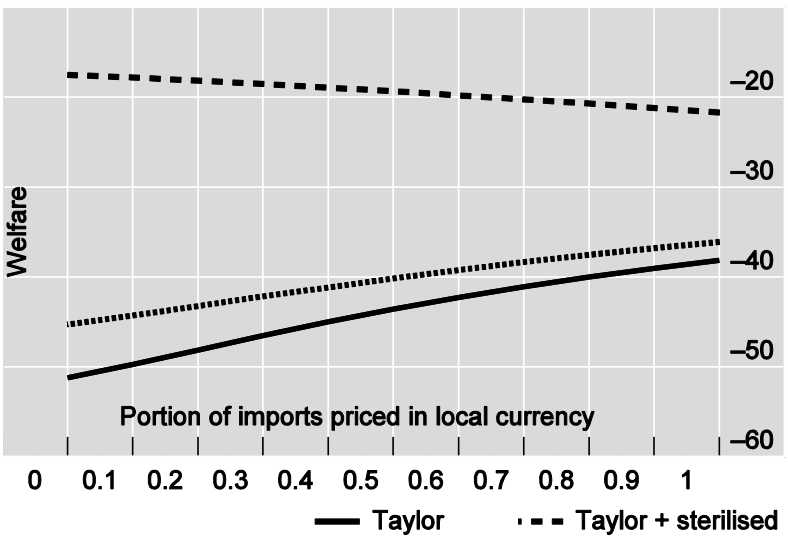

Financially open $(\lambda=1.0)$

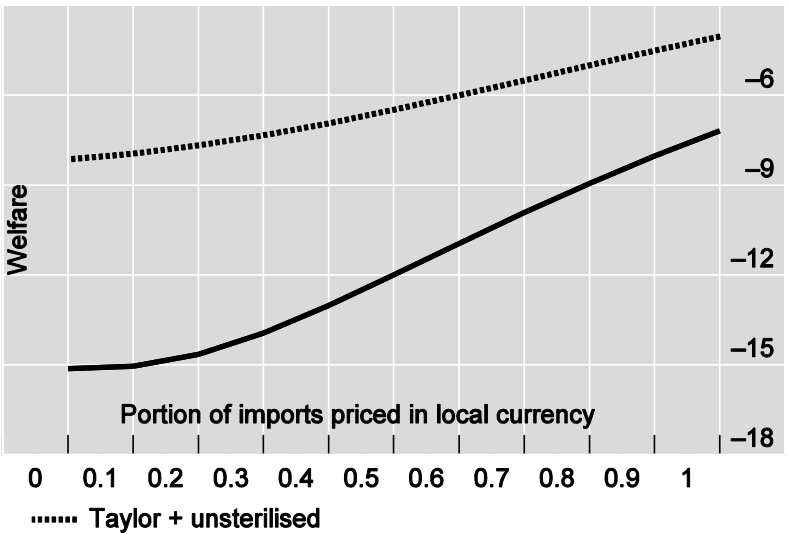

\section{Welfare effects of cost-push shocks}

Mixture of local and producer currency pricing $(\delta=0.5)^{\mathrm{a}}$
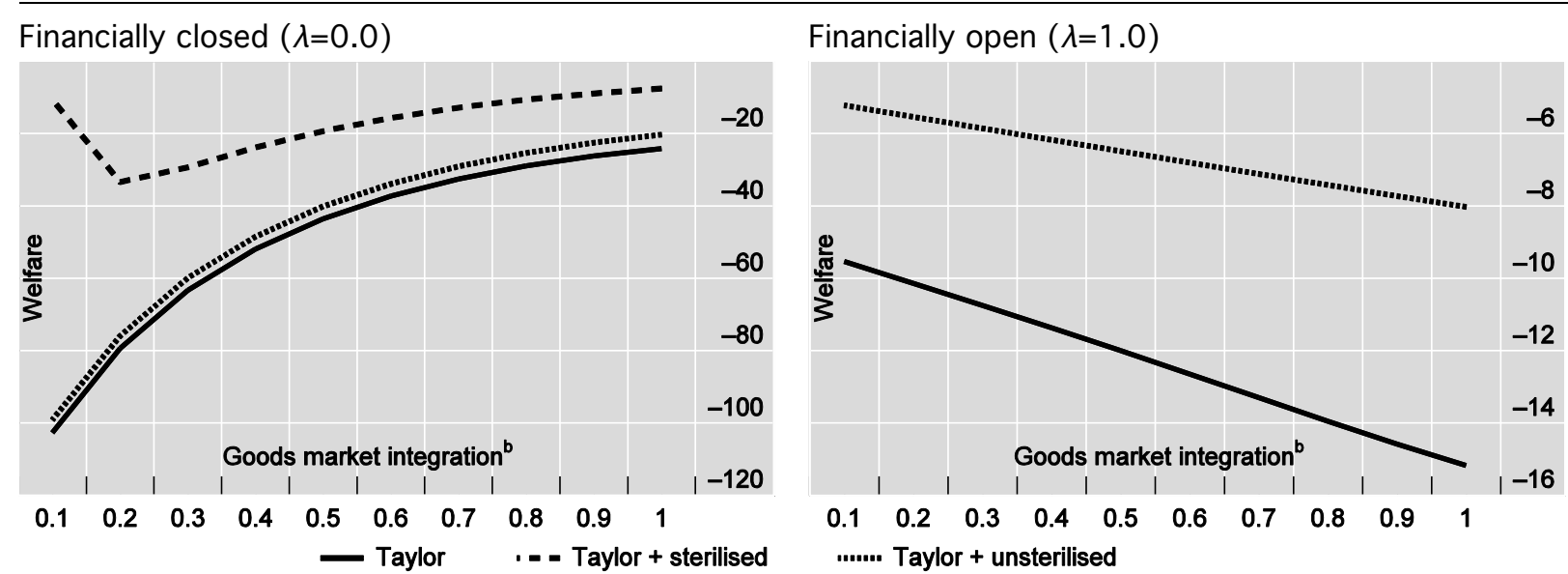

a Half of all import varieties are assumed to be priced in the local currency and half in the producer currency. b Goods market integration is defined as 2- $v$.

${ }^{21}$ For an analogous graph with cost-push shocks with costly foreign exchange reserves volatility, please see the appendix. 

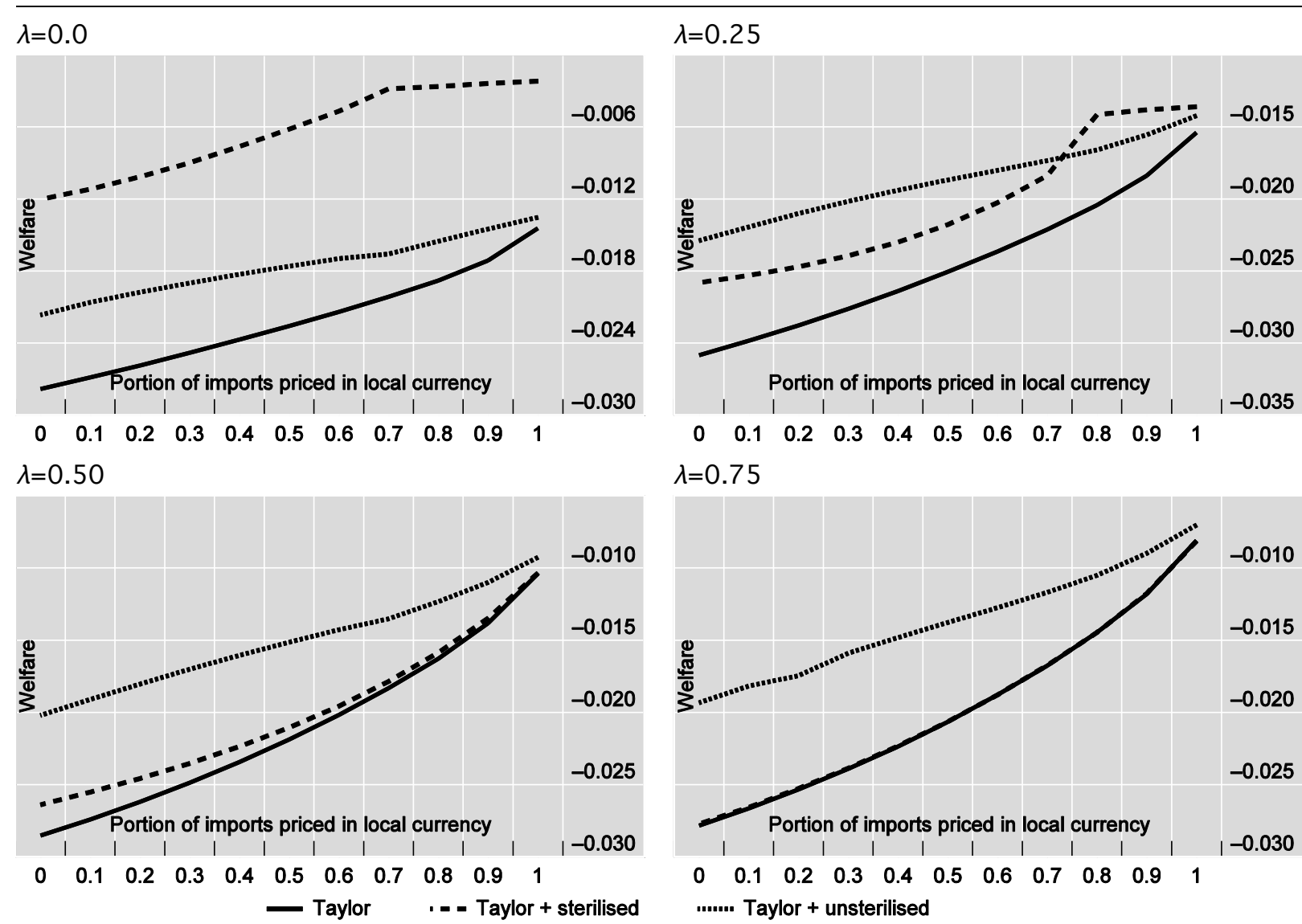

\section{$\lambda=0.75$}

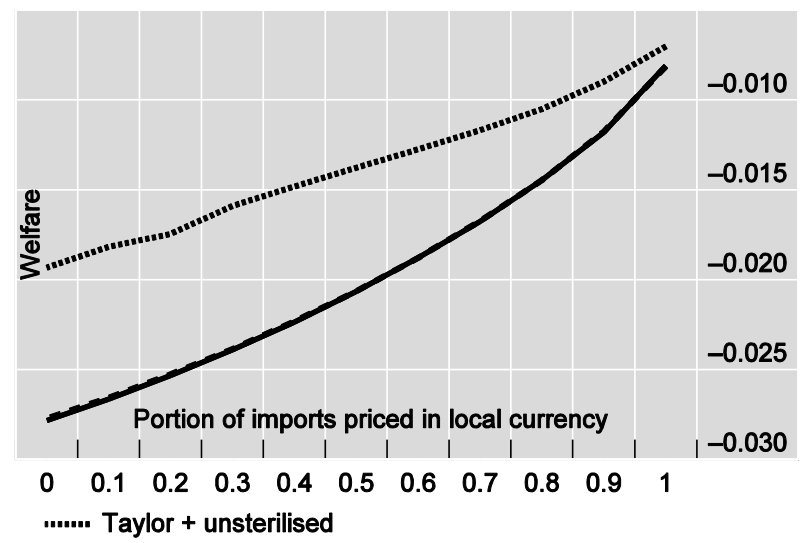

\section{Conclusions}

We have examined how monetary policy should respond to nominal exchange rate changes, with the hope of helping to inform the debate over the evolution of Asian monetary policy. We have shown how the optimal response to exchange rates depends on the degree of financial internationalisation, goods market integration and exchange rate pass-through. Sterilised intervention can be a potent tool that offers policymakers an additional degree of freedom in maximising global welfare. The potential welfare benefits from sterilised intervention are largest in our model if exchange rate pass-through is high or goods markets are poorly integrated, and in response to productivity shocks (less so with costpush shocks). However, as the international policy trilemma implies, our model suggests that there are limitations to the use of sterilised intervention. As financial internationalisation increases, achieving a given degree of exchange rate stability requires ever increasing changes in foreign exchange reserves. Taking into account the cost of volatile reserves, increased financial integration reduces the role for sterilised intervention. In the case of fully integrated international financial markets, sterilised intervention has no influence on exchange rates at all.

Where sterilised intervention is no longer a desirable policy tool, unsterilised intervention may have a role to play. However, the potential welfare gains from the optimal use of this tool in our model are relatively small. With unsterilised intervention, a single policy instrument (interest rates) is effectively being used to respond to an additional variable (exchange rates), compromising its response to inflation. In contrast, sterilised intervention represents an additional policy tool that does not impinge on the optimal interest rate response to other variables.

Many central banks in Asia have actively used sterilised foreign exchange intervention as a policy tool to smooth exchange rate movements over time. In our model, the use of sterilised intervention represents good policy when goods markets and financial markets are not well integrated 
internationally and exchange rate pass-through is high. But these characteristics are changing in the region. By most metrics, the degree of exchange rate pass-through has fallen. The combination of developing domestic financial markets, and declining barriers to international capital flows, has seen increased financial internationalisation. And goods markets have become more integrated as consumer preferences have moved closer together.

In our model, the effect of these changes is to reduce the benefits of stabilising exchange rates with sterilised foreign exchange intervention. And, given the limited effectiveness of unsterilised intervention, our results imply that the role of exchange rate movements in the optimal setting of monetary policy is decreasing across the region.

\section{Appendix}

Take a model of two economies, where households in each economy consume and choose how much to work, given wages and prices. The economies are referred to as 'home' and 'foreign'. The economies are of equal size (with populations normalised to unity). Consumption takes place across a range of differentiated goods. Asset markets are complete within economies. Between economies, we construct a mechanism which allows for asset market completeness to vary between financial autarky and a full set of security markets. Firms produce goods, but product prices are sticky. We allow for prices of exported goods to be set either in the currency of the producer (PCP) or the buyer (LCP). In addition, we allow for home bias in consumption preferences, so that we can vary the degree of goods market integration.

\section{A.1 Households}

Let the utility of a representative home household evaluated from date zero be defined as:

$$
U_{t}=E_{0} \sum_{t=0}^{\infty} \beta^{t}\left(U\left(C_{t}\right)-V\left(N_{t}\right)\right)
$$

where $U$ and $V$ represent the utility of the composite home consumption bundle $C_{t}$ and disutility of labour supply $N_{t}$, respectively. $U$ is differentiable and concave in $C$, while $V$ is differentiable and convex in $N$. Consumption is defined as:

$$
C_{t}=\Phi C_{H t}^{v / 2} C_{F t}^{1-v / 2},
$$

where $v \geq 1, \Phi=(v / 2)^{v / 2}(1-v / 2)^{1-v / 2}, C_{H t}$ is consumption of the home economy composite good and $C_{F t}$ is consumption of the foreign composite. The parameter $v$ allows for home bias in preferences. In addition, $C_{H t}$ and $C_{F t}$ are defined over the range of home and foreign differentiated goods with elasticity of substitution $\theta>1$ between goods, so that:

$$
C_{H}=\left[\int_{0}^{1} C_{H}(i)^{\frac{\theta-1}{\theta}} d i\right]^{\frac{\theta}{\theta-1}}, \quad C_{F}=\left[\int_{0}^{1} C_{F}(i)^{\frac{\theta-1}{\theta}} d i\right]^{\frac{\theta}{\theta-1}} .
$$

Price indices for home and foreign consumption may be written as:

$$
P_{H}=\left[\int_{0}^{1} P_{H}(i)^{1-\theta} d i\right]^{\frac{1}{1-\theta}}, \quad P_{F}=\left[\int_{0}^{1} P_{F}(i)^{1-\theta} d i\right]^{\frac{1}{1-\theta}},
$$

while the aggregate (CPI) price index for the home economy is $P=P_{H}^{v / 2} P_{F}^{1-v / 2}$. In addition to this decomposition, we assume that foreign goods consumption can be further differentiated between PCP goods and LCP goods, with shares of $(1-\delta)$ and $\delta$ respectively. This allows us to vary the measure of export prices which are set in home and foreign currency, but has no effect on the flexible price equilibrium of the model. 
The representative home economy household sells labour services to each of a continuum of home economy firms, and receives a nominal wage $W_{t}$ in return. The household's implicit labour supply is determined by the condition:

$$
U_{c}\left(C_{t}\right) W_{t}=P_{t} V^{\prime}\left(N_{t}\right) .
$$

We assume that there is a full set of state-contingent securities traded between home and foreign residents. However, there is a state-contingent wedge in the security returns that prevents the equalisation of marginal utilities of asset returns between households in the two economies. Denote this wedge as $\Omega_{t}$. Then we have the risk-sharing relationship given by:

$$
U_{c}\left(C_{t}\right)=U_{c}\left(C_{t}^{*}\right) \frac{P_{t}}{S_{t} P_{t}^{*}} \Omega_{t},
$$

where $S_{t}$ is the nominal exchange rate (home price of foreign currency). The real exchange rate $S_{t} P_{t}^{*} / P_{t}$ will be driven by two factors: a) deviations from the law of one price in home and foreign goods, due to local currency pricing, and b) movements in the terms of trade (price of foreign to home goods) which, in the presence of home bias in consumption, will drive movements in the relative CPI's over time. We assume that the wedge in risk-sharing is governed by the functional relationship:

$$
\Omega_{t}=\left(\frac{P_{t} C_{t}}{\bar{P}_{t} Y_{t}-\Delta\left(F R_{t}\right)}\right)^{\frac{1-\lambda}{\lambda}},
$$

where $Y_{t}$ represents home economy GDP, an average of the output of all home firms, $\bar{P}_{t}$ is the average selling price of all goods produced by home firms and $\Delta\left(F R_{t}\right)$ is the change in the stock of foreign exchange reserves. This form can be rationalized by the presence of lump-sum financed taxes that are conditioned on the ratio of consumption to domestic GDP. The usefulness of (11) is that it allows us to vary the effective degree of asset market completeness between that of complete international risk-sharing $(\lambda=1)$ to financial autarky $(\lambda=0){ }^{22}$

We assume also that households hold domestic nominal government bonds, which pay an interest rate of $R_{t}$ in all states of the world. Then the Euler equation for nominal bond pricing is given by:

$$
\frac{U_{c}\left(C_{t}\right)}{P_{t}}=\beta R_{t+1} E_{t} \frac{U_{c}\left(C_{t+1}\right)}{P_{t+1}} .
$$

Foreign households' actions are analogous. As we see from the definition of $P_{t}^{*}$ given above, the foreign representative household has weight $v / 2$ on the foreign (and $(1-v / 2)$ on the home) composite good.

\section{A.2 Firms}

Firms use labour to produce individual differentiated goods. Firm $i$ in the home economy has the production function:

$$
Y_{t}(i)=A_{t} N_{t}(i)
$$

where $A_{t}$ is productivity. The home firm's profits are defined by:

\footnotetext{
22 The form of this risk-sharing wedge is also used in Devereux and Yetman (2014). The appeal of (11) is that it allows for intermediate degrees of asset market completeness without adding any additional state variables into the model (as would be the case if we limited asset trade across economies to that of non-state contingent bonds, for example).
} 


$$
\Pi_{t}(i)=P_{t}(i) Y_{t}(i)-\left(1-s_{t}\right) W_{t} N_{t}(i),
$$

where $s_{t}$ is a wage subsidy given to all home firms by the home government, financed with lump-sum taxation. This facilitates approximation of the model around an undistorted steady state.

We assume that each home firm re-sets its price according to Calvo pricing, with constant probability of re-adjusting its price each period of $(1-\kappa)$. Under PCP the home firm sells its product to home and foreign consumers, and the home government, at a common price (adjusted for the exchange rate in the case of exported goods), facing an elasticity of demand of $\theta$. When the firm can adjust its price, it sets the new price, denoted $\hat{P}_{H t}(i)$, so as to maximize the present value of profits evaluated using the stochastic discount factor:

$$
m_{t+j}=\frac{P_{t}}{U_{c}\left(C_{t}\right)} \frac{U_{c}\left(C_{t+j}\right)}{P_{t+j}} .
$$

This leads to the optimal price setting condition as follows:

$$
\hat{P}_{H t}(i)=\frac{\theta}{\theta-1}\left(1-s_{t}\right) \frac{E_{t} \sum_{j=0}^{\infty} m_{t+j} \kappa^{j} W_{t+j} Y_{t+j}(i)^{p c p} / A_{t+j}}{E_{t} \sum_{j=0}^{\infty} m_{t+j} \kappa^{j} Y_{t+j}(i)^{p c p}},
$$

where $Y_{t}(i)^{p c p}$ indicates the demand for goods produced by home firms engaged in PCP pricing from both home and foreign consumers. All PCP home firms that can adjust their price choose the same price. In the aggregate, the PCP price index for the home good is:

$$
P_{H t}=\left[(1-\kappa) \hat{P}_{H t}^{1-\theta}+\kappa P_{H t-1}^{1-\theta}\right]^{\frac{1}{1-\theta}} .
$$

For domestic firms who price their goods abroad using LCP, the pricing of goods sold to home consumers parallels the above. The price for foreign consumers (in foreign currency) is defined as:

$$
\hat{P}_{H t}^{*}(i)=\frac{\theta}{\theta-1}\left(1-S_{t}\right) \frac{E_{t} \sum_{j=0}^{\infty} m_{t+j} \kappa^{j} W_{t+j} Y_{t+j}(i)^{l c p, f} / A_{t+j}}{E_{t} \sum_{j=0}^{\infty} m_{t+j} \kappa^{j} S_{t+j} Y_{t+j}(i)^{l c p, f}},
$$

where $S_{t+j}$ is the nominal exchange rate at time $t+j$, and $Y_{t+j}(i)^{l c p, f}$ denotes the foreign demand for the LCP-priced home good of firm $i$. Again, all LCP home firms that can adjust their price choose the same price. In the aggregate, the LCP price index for the home good then follows:

$$
P_{H t}^{*}=\left[(1-\kappa) \hat{P}_{H t}^{*(1-\theta)}+\kappa P_{H t-1}^{*(1-\theta)}\right]^{\frac{1}{1-\theta}} .
$$

The behaviour of foreign firms and the foreign good price index may be described analogously.

\section{A.3 Monetary Policy}

We assume that monetary policy is governed by an augmented Taylor rule given by:

$$
R_{t}^{r}=(1+\rho)(1+\breve{\pi})(1+\breve{s})\left(\frac{P_{t}}{P_{t-1}} \frac{1}{1+\breve{\pi}}\right)^{\zeta}\left(\frac{S_{t}}{S_{t-1}} \frac{1}{1+\breve{s}}\right)^{\gamma},
$$

where $\rho$ represents a desired equilibrium real interest rate and $\breve{\pi}$ and $\breve{S}$ represent the desired path for the home economy inflation rate and the rate of change of the nominal exchange rate respectively. We assume that $\zeta>1$. This rule does not allow for interest rate 'smoothing'. This simplification allows for simple analytical solutions to the model, but is not critical for the results. The monetary policy rule for the foreign economy is characterised in an analogous manner, with the exception that foreign interest rates do not respond to exchange rates. We also allow for a foreign exchange rate policy which, when $\lambda<1$, is equivalent to sterilised intervention, characterised by (4). 


\section{A.4 Market Clearing}

Each home economy firm $i$ faces demand for its good from home consumers, foreign consumers and its home government. Take first the PCP pricing home firm. It sets the same price in the home and foreign market, in home currency. We can define equilibrium in the market for good $i$ as:

$$
Y_{t}(i)^{p c p}=\left(\frac{P_{H t}(i)}{P_{H t}}\right)^{-\theta}\left[\frac{v}{2} \frac{P_{t}}{P_{H t}} C_{t}+\left(1-\frac{v}{2}\right)(1-\delta) \frac{S_{t} P_{t}^{*}}{P_{H t}} C_{t}^{*}\right],
$$

where $(1-\delta)$ comes from the fact that a share $\delta$ of home goods sold abroad are sold by LCP pricing home firms. Now, aggregating across all home firms, market clearing for the PCP-pricing home good is defined as:

$$
Y_{t}^{p c p}=\frac{v}{2} \frac{P_{t}}{P_{H t}} C_{t}+\left(1-\frac{v}{2}\right)(1-\delta) \frac{S_{t} P_{t}^{*}}{P_{H t}} C_{t}^{*}
$$

Here $\quad Y_{t}^{p c p}=V_{t}^{-1} \int_{0}^{1} Y_{t}(i)^{p c p} d i \quad$ is aggregate home economy PCP output, where $V_{t}=\int_{0}^{1}\left(P_{H t}(i) / P_{H t}\right)^{-\theta} d i$. It follows that home economy PCP employment (employment for the representative home household) is given by $N_{t}^{p c p}=\int_{0}^{1} N_{t}(i)^{p c p} d i=A^{-1} Y_{t}^{p c p} V_{t} \cdot{ }^{23}$

For the LCP firm, output is divided between that sold to home consumers in home currency and foreign consumers in foreign currency. We define equilibrium in the market for its good as:

$$
\begin{gathered}
Y_{t}(i)^{l c p, h}=\left(\frac{P_{H t}(i)}{P_{H t}}\right)^{-\theta}\left[\frac{v}{2} \frac{P_{t}}{P_{H t}} C_{t}\right], \\
Y_{t}(i)^{l c p, f}=\left(\frac{P_{H t}^{*}(i)}{P_{H t}^{*}}\right)^{-\theta}\left[\left(1-\frac{v}{2}\right) \delta \frac{P_{t}^{*}}{P_{H t}^{*}} C_{t}^{*}\right] .
\end{gathered}
$$

We aggregate over each of these terms separately and define aggregate output for LCP firms as:

$$
Y_{t}^{l c p}=Y_{t}^{l c p, h}+Y_{t}^{l c p, f} \text {. }
$$

Total home GDP in the linear approximation of the model ends up simply being a weighted sum of $Y_{t}^{p c p}$ and $Y_{t}^{l c p}$. We follow an analogous approach for foreign firms under both PCP and LCP pricing.

\section{A.5 Shocks}

We consider productivity shocks $\left(a_{t}, a_{t}^{*}\right)$ and cost-push shocks $\left(u_{t}, u_{t}^{*}\right)$. We assume that these are independent and each follow $\operatorname{AR}(1)$ processes with autoregressive parameter 0.9.

\section{A.6 Linear approximation}

We linearise our model around the flexible-price, zero foreign reserves, steady-state. Our model reduces to a 12-equation log-linearised system, as follows:

Home goods market equilibrium:

$$
y_{t}=\frac{v}{2} c_{t}+\left(1-\frac{v}{2}\right) c_{t}^{*}+v\left(1-\frac{v}{2}\right)\left(\tau_{t}+(1-\delta) \Delta_{t}\right) .
$$

\footnotetext{
${ }^{23}$ Note that these $V_{t}$ terms drop out in the linear approximation of the model.
} 
Foreign goods market equilibrium:

$$
y_{t}^{*}=\frac{v}{2} c_{t}^{*}+\left(1-\frac{v}{2}\right) c_{t}-v\left(1-\frac{v}{2}\right)\left(\tau_{t}+(1-\delta) \Delta_{t}\right) .
$$

Risk-sharing / international financial market equilibrium:

$$
\begin{aligned}
& \lambda\left[\sigma\left(c_{t}-c_{t}^{*}\right)-\delta \Delta_{t}-(v-1)\left(\tau_{t}+(1-\delta) \Delta_{t}\right)\right] \\
& +(1-\lambda)\left[c_{t}+\left(1-\frac{v}{2}\right)\left(\tau_{t}+(1-2 \delta) \Delta_{t}\right)-y_{t}+\left(f r_{t}-f r_{t-1}\right)\right]=0 .
\end{aligned}
$$

Inflation equation for home goods sold at home:

$$
\pi_{H t}=\kappa\left[\sigma c_{t}+\phi\left(y_{t}-a_{t}\right)-a_{t}+u_{t}+\left(1-\frac{v}{2}\right)\left(\tau_{t}+(1-\delta) \Delta_{t}\right)\right]+u_{t}+\beta E_{t} \pi_{H t+1} .
$$

Inflation equation for home goods sold in the foreign market with local currency pricing:

$$
\pi_{H t}^{*}=\kappa\left[\sigma c_{t}+\phi\left(y_{t}-a_{t}\right)-a_{t}+u_{t}+\left(1-\frac{v}{2}\right)\left(\tau_{t}+(1-\delta) \Delta_{t}\right)-\Delta_{t}\right]+u_{t}+\beta E_{t} \pi_{H t+1}^{*} .
$$

Inflation equation for foreign goods sold in the foreign market:

$$
\pi_{F t}^{*}=\kappa\left[\sigma c_{t}^{*}+\phi\left(y_{t}^{*}-a_{t}^{*}\right)-a_{t}^{*}+u_{t}^{*}-\left(1-\frac{v}{2}\right)\left(\tau_{t}+(1-\delta) \Delta_{t}\right)\right]+u_{t}^{*}+\beta E_{t} \pi_{F t+1}^{*} .
$$

Inflation equation for foreign goods sold in the home market with local currency pricing:

$$
\pi_{F t}=\kappa\left[\sigma c_{t}^{*}+\phi\left(y_{t}^{*}-a_{t}^{*}\right)-a_{t}^{*}+u_{t}^{*}-\left(1-\frac{v}{2}\right)\left(\tau_{t}+(1-\delta) \Delta_{t}\right)+\Delta_{t}\right]+u_{t}^{*}+\beta E_{t} \pi_{F t+1} .
$$

Inflation equation for foreign goods sold in the home market with both local currency pricing and producer currency pricing:

$$
\tilde{\pi}_{F t}=\pi_{H t}+\left(\tau_{t}-\tau_{t-1}+(1-\delta)\left(\Delta_{t}-\Delta_{t-1}\right)\right) .
$$

Inflation equation for home goods sold in the foreign market with both local currency pricing and producer currency pricing:

$$
\tilde{\pi}_{H t}^{*}=\pi_{F t}^{*}-\left(\tau_{t}-\tau_{t-1}+(1-\delta)\left(\Delta_{t}-\Delta_{t-1}\right)\right) .
$$

Home investment-savings equation (from the monetary policy rule, including an interest rate response to the change in the nominal exchange rate and home $\mathrm{CPI}$ inflation, and the Euler equation):

$$
\begin{gathered}
\gamma\left[\Delta_{t}-\Delta_{t-1}-\left(\pi_{F t}^{*}-\pi_{F t}\right)\right]+\zeta\left[\frac{v}{2} \pi_{H t}+\left(1-\frac{v}{2}\right) \tilde{\pi}_{F t}\right] \\
=E_{t}\left[\frac{v}{2} \pi_{H t+1}+\left(1-\frac{v}{2}\right) \tilde{\pi}_{F t+1}\right]+\sigma E_{t}\left(c_{t+1}-c_{t}\right),
\end{gathered}
$$

where $\Delta_{t}-\Delta_{t-1}-\left(\pi_{F t}^{*}-\pi_{F t}\right)=s_{t}-s_{t-1}$ is the change in the nominal exchange rate.

Foreign investment-savings equation (from the monetary policy rule, incorporating an interest rate response to foreign $\mathrm{CPI}$ inflation, and the Euler equation):

$$
\zeta^{*}\left[\frac{v}{2} \pi_{F t}^{*}+\left(1-\frac{v}{2}\right) \tilde{\pi}_{H t}^{*}\right]=E_{t}\left[\frac{v}{2} \pi_{F t+1}^{*}+\left(1-\frac{v}{2}\right) \tilde{\pi}_{H t+1}^{*}\right]+\sigma E_{t}\left(c_{t+1}^{*}-c_{t}^{*}\right) .
$$


Terms of trade equation:

$$
\begin{aligned}
\tau_{t}-\tau_{t-1}= & \kappa\left(\phi\left(y_{t}^{*}-y_{t}\right)+\sigma\left(c_{t}^{*}-c_{t}\right)+(v-1)\left(\tau_{t}+(1-\delta) \Delta_{t}\right)+\delta \Delta_{t}-\tau_{t}+(1+\phi)\left(a_{t}-a_{t}^{*}\right)\right) \\
& +\beta E_{t}\left(\tau_{t+1}-\tau_{t}\right) .
\end{aligned}
$$

Welfare in this model depends in part on output levels relative to their flexible-price equilibrium values. Solving for flexible prices $(\kappa=0)$ yields the following five-equation system:

$$
\begin{gathered}
\tilde{y}_{t}=\frac{v}{2} \tilde{c}_{t}+\left(1-\frac{v}{2}\right) \tilde{c}_{t}^{*}+v\left(1-\frac{v}{2}\right) \tilde{\tau}_{t}, \\
\tilde{y}_{t}^{*}=\frac{v}{2} \tilde{c}_{t}^{*}+\left(1-\frac{v}{2}\right) \tilde{c}_{t}-v\left(1-\frac{v}{2}\right) \tilde{\tau}_{t}, \\
\lambda\left[\sigma\left(\tilde{c}_{t}-\tilde{c}_{t}^{*}\right)-(v-1) \tilde{\tau}_{t}\right]+(1-\lambda)\left[\tilde{c}_{t}+\left(1-\frac{v}{2}\right) \tilde{\tau}_{t}-\tilde{y}_{t}\right]=0, \\
\sigma \tilde{c}_{t}+\phi\left(\tilde{y}_{t}-a_{t}\right)-a_{t}+\left(1-\frac{v}{2}\right) \tilde{\tau}_{t}=0, \\
\sigma \tilde{c}_{t}^{*}+\phi\left(\tilde{y}_{t}^{*}-a_{t}^{*}\right)-a_{t}^{*}-\left(1-\frac{v}{2}\right) \tilde{\tau}_{t}=0,
\end{gathered}
$$

where indicates flexible-price allocation. Then, up to a second-order approximation, the welfare function for a given $\lambda$ is given by:

$$
\begin{aligned}
V_{t}= & -\frac{1}{4} \frac{D_{1} D_{3}}{D_{2}{ }^{2}}(2-v(1-\lambda))^{2} \delta^{2} \Delta_{t}{ }^{2}-(\sigma+\phi) y_{t w}{ }^{2}-(1+\phi) y_{t r}{ }^{2} \\
& -\frac{(\sigma-1)(v-1)^{2}}{D_{2}{ }^{2}}(2-v(1-\lambda))^{2} y_{t r}{ }^{2}-4 D_{3}\left(\frac{\lambda(\sigma-1)(v-1)}{D_{2}}\right)^{2} y_{t r}{ }^{2} \\
& -\frac{D_{3}(2-v)(\sigma-1)(1-\lambda)(v-1) \delta}{D_{2}{ }^{2}}(2-v(1-\lambda)) y_{t r} \Delta_{t} \\
& -\frac{\theta}{2 \kappa}\left(\left(\frac{v}{2}+(1-\delta)\left(1-\frac{v}{2}\right)\right) \pi_{H t}{ }^{2}+\frac{2-v}{2} \delta \pi_{F t}{ }^{2}+\left(\frac{v}{2}+(1-\delta)\left(1-\frac{v}{2}\right)\right) \pi_{F t}^{*}+\frac{2-v}{2} \delta \pi_{H t}^{*}\right),
\end{aligned}
$$

where

$$
D_{1}=\sigma v(2-v)+(1-v)^{2}
$$$$
D_{2}=2 D_{1} \lambda+(1-\lambda)(2-v),
$$$$
D_{3}=v(2-v),
$$

$y_{t r}=\frac{1}{2}\left[\left(y_{t}-\tilde{y}_{t}\right)-\left(y_{t}^{*}-\tilde{y}_{t}^{*}\right)\right]$ and $y_{t w}=\frac{1}{2}\left[\left(y_{t}-\tilde{y}_{t}\right)+\left(y_{t}^{*}-\tilde{y}_{t}^{*}\right)\right]$. 

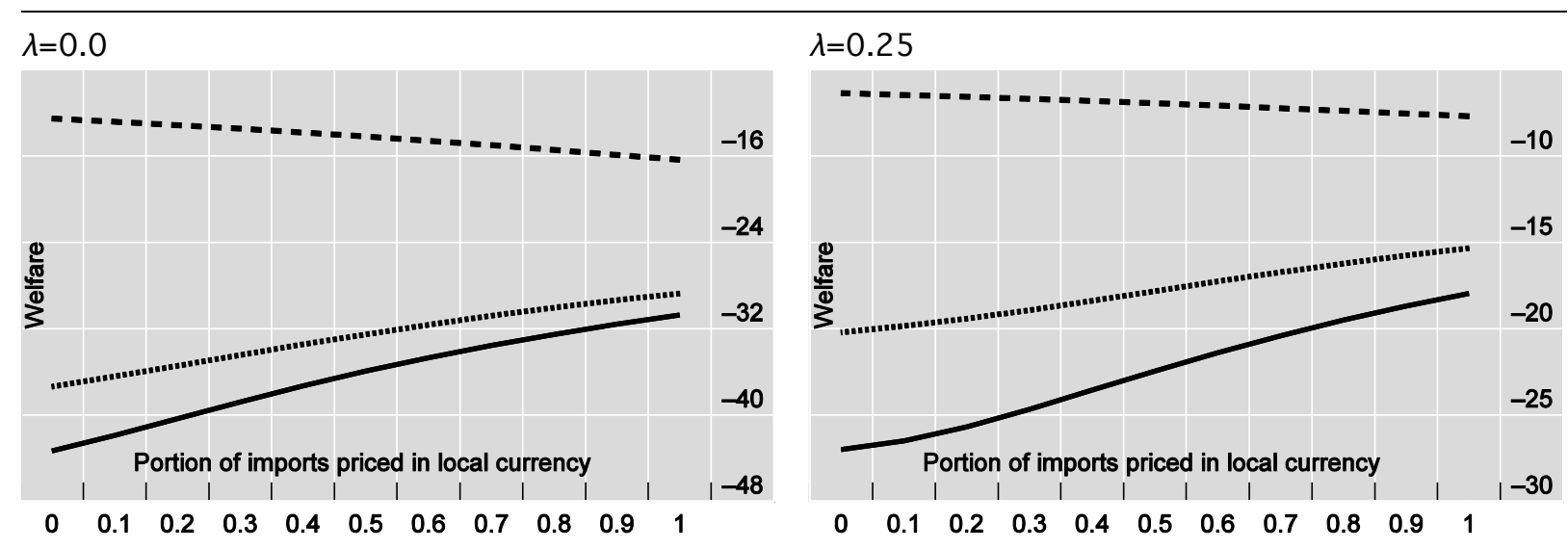

$\lambda=0.50$

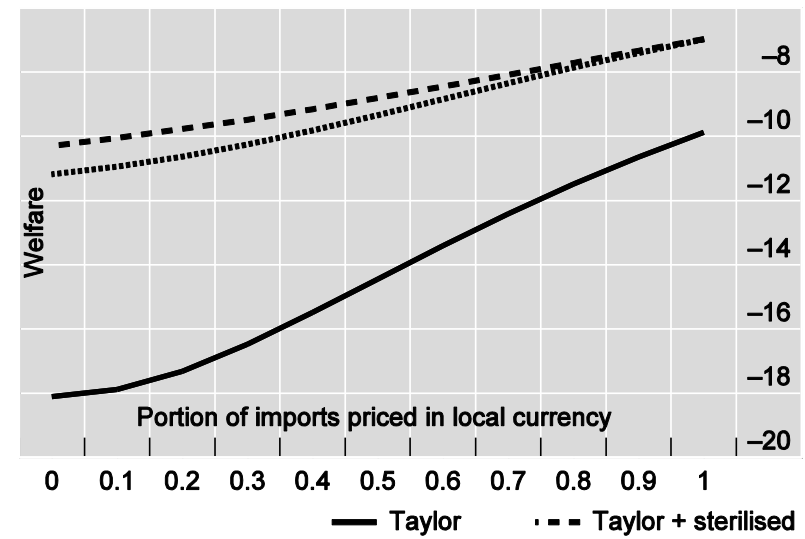

\section{$\lambda=0.75$}

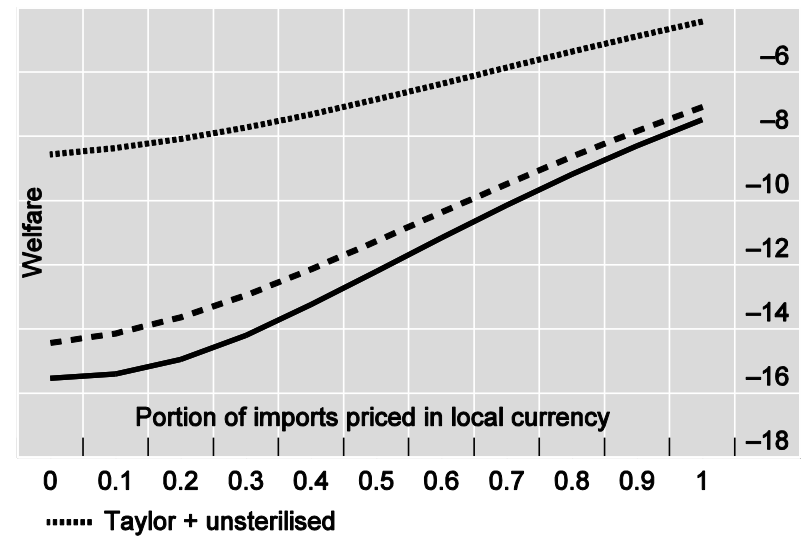

\section{References}

Aizenman, Joshua and Reuven Glick (2009): "Sterilization, monetary policy, and global financial integration," Review of International Economics 17(4), 777-801.

Bacchetta, Philippe, Kenza Benhima and Yannick Kalantzis (2013): "Capital controls with international reserve accumulation: can this be optimal?" American Economic Journal: Macroeconomics 5(3), 229-262.

Bai, Yan and Jing Zhang (2012): "Financial integration and international risk sharing," Journal of International Economics 86(1), 17-32.

Benes, Jaromir, Andrew Berg, Rafael A Portillo and David Vavra (2013): "Modeling sterilised interventions and balance sheet effects of monetary policy in a New-Keynesian framework," IMF Working Paper 13/11.

Benigno, Gianluca and Pierpaolo Benigno (2006): "Designing targeting rules for international monetary policy cooperation," Journal of Monetary Economics 53(3), 473-506.

Berka, Martin, Michael B Devereux and Charles Engel (2012): "Real exchange rate adjustment in and out of the Eurozone," American Economic Review 102(3), 179-85.

Brun-Aguerre, Raphael, Ana-Maria Fuertes and Kate Phylaktis (2012): "Exchange rate pass-through into import prices revisited: what drives it?" Journal of International Money and Finance 31(4), 818-844. 
Burstein, Arial and Gita Gopinath (2013): "International prices and exchange rates," NBER Working Paper 18829.

Calvo, Guillermo A and Carmen M Reinhart (2002): "Fear of floating," Quarterly Journal of Economics 117(2), 379-408.

Campa, Jose Manuel and Linda S Goldberg (2005): "Exchange rate pass-through into import prices," Review of Economics and Statistics 87(4), 679-690.

Cavoli, Tony and Ramkishen S Rajan (2006): "Capital inflows problem in selected Asian economies in the 1990s revisited: the role of monetary sterilization," Asian Economic Journal 20(4), 409-423.

Ca'Zorzi, Michele, Elke Hahn and Marcelo Sánchez (2007): "Exchange rate pass-through in emerging markets," ECB Working Paper 739.

Catão, Luis A V and Roberto Chang (2013): "World food prices, the terms of trade-real exchange rate nexus, and monetary policy," IMF Working Paper 13/114.

Cespedes, Luis Felipe, Roberto Chang and Andres Velasco (2004): "Balance sheets and exchange rate policy," American Economic Review 94(4), 1183-1193.

Choi, Woon Gyu and David Cook (2013): "Import price misalignment after the crisis: a New Keynesian perspective," http://www.imf.org/external/np/seminars/eng/2012/korea/pdf/choi.pdf.

Choudry, Ehsan U and Dalia S Hakura (2006): "Exchange rate pass-through to domestic prices: does the inflationary environment matter?" Journal of International Money and Finance 25(4), 614-639.

Clarida, Richard, Jordi Galí and Mark Gertler (2002): "A simple framework for international monetary policy analysis," Journal of Monetary Economics 49(5), 879-904.

Cook, David and Michael B Devereux (2013): "Sharing the burden: monetary and fiscal responses to a world liquidity trap," American Economic Journal: Macroeconomics 5(3), 190-228.

Cook, David and Michael B Devereux (2006): "External currency pricing and the East Asian crisis," Journal of International Economics 69(1), 37-63.

Cook, David and James Yetman (2012): "Expanding central bank balance sheets in emerging Asia: a compendium of risks and some evidence," BIS Papers no 66, 30-75.

Corsetti, Giancarlo and Paolo Pesenti (2005): "International dimensions of optimal monetary policy," Journal of Monetary Economics 52(2), 281-305.

Devereux, Michael B (2004): "Should the exchange rate be a shock absorber?" Journal of International Economics 62(2), 359-377.

Devereux, Michael B and Charles Engel (2003): "Monetary policy in the open economy revisited: price setting and exchange-rate flexibility," Review of Economic Studies 70(4), 765-783.

Devereux, Michael B, Ozge Senay and Alan Sutherland (2013): "Nominal stability and financial globalization," Journal of Money, Credit and Banking, forthcoming.

Devereux, Michael B and Alan Sutherland (2008): "Financial globalization and monetary policy," Journal of Monetary Economics 55(8), 1363-1375.

Devereux, Michael B and James Yetman (2014): "Capital controls, global liquidity traps and the international policy trilemma," Scandinavian Journal of Economics 116(1), 158-189.

Devereux, Michael B and James Yetman (2010): "Price adjustment and exchange rate pass-through," Journal of International Money and Finance 29(1), 181-200.

Engel, Charles (2013): "Inflation and globalisation: a modeling perspective," BIS Papers no 70, 99108.

Engel, Charles (2014): "Exchange rate stabilization and welfare," Annual Review of Economics, forthcoming.

Engel, Charles (2011): "Currency misalignments and optimal monetary policy: a reexamination," American Economic Review 101(6), 2796-2822.

Filardo, Andrew and James Yetman (2012): "The expansion of central bank balance sheets in emerging Asia: what are the risks?" BIS Quarterly Review, June, 47-63. 
Filardo, Andrew, Guonan Ma and Dubravko Mihaljek (2011): "Exchange rates and monetary policy frameworks in EMEs," BIS Papers no 57, 37-63.

Gagnon, Joseph and Jane Ihrig (2004): "Monetary policy and exchange rate pass-through," International Journal of Finance and Economics 9(4), 315-338.

Garcia, Carlos J, Jorge E Restrepo and Scott Roger (2011): "How much should inflation targeters care about the exchange rate?" Journal of International Money and Finance 30(7), 1590-1617.

Goldberg, Linda S and Cédric Tille (2008): "Vehicle currency use in international trade," Journal of International Economics 76(2), 177-192.

Korinek, Anton and Luis Servén (2009): "Real exchange rate undervaluation: static losses, dynamic gains," http://siteresources.worldbank.org/INTMACRO/Resources/RERPaper.pdf.

Kose, M Ayhan, Eswar S Prasad and Marco E Terrones (2009): "Does financial globalization promote risk sharing?" Journal of Development Economies 89(2), 258-270.

Mihaljek, Dubravko and Marc Klau (2008): "Exchange rate pass-through in emerging market economies: what has changed and why?" BIS Papers no 35, 103-130.

Mohanty, M S and Marc Klau (2004): "Monetary policy rules in emerging market economies: issues and evidence," BIS Working Papers no 149.

Moron, Eduardo and Diego Winkelried (2005): "Monetary policy rules for financially vulnerable economies," Journal of Development Economics 76(1), 23-51.

Mussa, Michael, Paul Masson, Alexander Swoboda, Esteban Jadresic, Paolo Mauro and Andy Berg (2000): "Exchange rate arrangements of developing and transition countries," IMF Occasional Paper 193, 13-35.

Ostry, Jonathan D, Atish R Ghosh and Marcos Chamon (2012): "Two targets, two instruments: monetary and exchange rate policies in emerging market economies," IMF Staff Discussion Note $12 / 01$.

Ouyang, Alice Y and Ramkishen S Rajan (2011): "Reserve accumulation and sterilization in Singapore and Taiwan," Applied Economics 43(16), 2015-2031.

Parsley, David C and Helen A Popper (1998): "Exchange rates, domestic prices, and central bank actions: recent US experience," Southern Economic Journal 64(4), 957-972.

Prasad, Nalini (2013): "Sterilized interventions and capital controls," manuscript.

Reyes, Javier A (2007): "Exchange rate passthrough effects and inflation targeting in emerging economies: what is the relationship?" Review of International Economics 15(3), 538-559.

Sutherland, Alan (2005): "Incomplete pass-through and the welfare effects of exchange rate variability," Journal of International Economics 65(2), 375-399.

Taylor, John B (2001): "The role of the exchange rate in monetary policy rules," American Economic Review 91(2), 263-267.

Wong, Chin-Yoong, Yoke-Kee Eng and Muzafar Shah Habibullah (2014): "Rising China, anxious Asia? A Bayesian New Keynesian view," China Economic Review 28, 90-106.

Woodford, Michael (2003): "Interest and Prices," Princeton University Press, Princeton, New Jersey. 